\title{
Microwave-accelerated Mizoroki-Heck and Sonogashira cross- coupling reactions in water using a heterogeneous palladium(II)-precatalyst
}

\author{
Kamal M. Dawood, ${ }^{\text {a,b }}$ Wladimir Solodenko, and Andreas Kirschning a,* \\ a Institut für Organische Chemie, Leibniz Universität Hannover, Schneiderberg 1b, 30167 \\ Hannover; Germany, \\ ${ }^{b}$ Department of Chemistry, Faculty of Science, Cairo University, Giza 12613, Egypt \\ E-mail: andreas.kirschning@oci.uni-hannover.de
}

Dedicated to Prof. Dr. Dr. h.c. Lutz F. Tietze on the occasion of his 65th birthday

\begin{abstract}
The catalytic activity of a 2-pyridinealdoxime-based Pd(II)-complex covalently anchored via the oxime moiety to a glass/ polymer composite material was evaluated both under thermal as well as microwave $(\mu \mathrm{w})$ irradiating conditions in water in Mizoroki-Heck as well as Sonogashira C-C cross-coupling reactions. Synthesis of benzo[b]furan derivatives via Sonogashira cross coupling reaction was achieved when ortho-halo-phenols were employed as aryl halides. The stability and reusability of this Pd-precatalyst was part of the present study.
\end{abstract}

Keywords: Catalysis, immobilization, microwave, Mizoroki-Heck reaction, palladium, Sonogashira reaction

\section{Introduction}

Heterogenization of organotransition metal complexes, ${ }^{1}$ particularly based on palladium, offers several significant practical advantages for synthetic chemistry, including industrial applications. $^{2}$ Among these, the ease of separation of the catalyst from the desired reaction products and the ease of recovery, as well as reuse of the catalyst are most significant. The inherent problem of heterogenization of homogeneous catalysts or precatalysts is associated with disfavored kinetics of the biphasic catalytic system compared to the monophasic counterpart in solution. One way to overcome this drawback is the use of microwave irradiation. ${ }^{3}$ Indeed, combined microwave-assisted solid-phase technique using homogeneous palladium catalysts has recently been used in several $\mathrm{C}-\mathrm{C}$ cross coupling reactions. ${ }^{4}$ In this context, we reported on the use of heterogeneous Pd-precatalysts based on 2-pyridinealdoxime in Suzuki-Miyaura cross 
coupling reactions under microwave irradiating $(\mu \mathrm{w})$ conditions. ${ }^{5}$ The Suzuki-Miyaura reaction is particularly well suited because it can be performed in aqueous suspensions which allow submission of microwaves as heating medium.

Other important Pd-catalyzed C-C coupling reactions are the Mizoroki-Heck ${ }^{6}$ and Sonogashira ${ }^{7,8}$ reactions which can be carried out using palladacycles as precatalysts. ${ }^{9}$ However, applications of palladacycles in these type of cross coupling reactions which are anchored to a solid phase are still limited. ${ }^{10-14}$ The examples of immobilized palladacycles studied so far were found to be highly active in Mizoroki-Heck and Sonogashira C-C-cross coupling reactions but turned out to be not well suited for recycling protocols. For example, the precatalyst 1 lost most of its activity after the first run under Mizoroki-Heck reaction conditions between iodobenzene and styrene. ${ }^{10}$ The authors used $N$-methylpyrrolidinone (NMP) as solvent which has good coordinative properties and therefore may account for the rapid removal of $\mathrm{Pd}$ from the solid support. The Pd(II)-complex 2, studied by Luo et al., ${ }^{11}$ supports this rationalization as it was found to be active and recyclable in Mizoroki-Heck and Sonogashira reactions only when ether was used as solvent. However, it failed to be reusable in polar solvents. The authors encountered a reaction time of $72 \mathrm{~h}$ for the Sonogashira- and $48 \mathrm{~h}$ for the Mizoroki-Heck cross coupling reaction of $p$-bromoacetophenone with phenylacetylene and styrene, respectively. Bergbreiter ${ }^{12}$ reported on precatalyst $\mathbf{3}$ to be active and recyclable in Mizoroki-Heck reactions with aryl iodides. In addition, complex 4 was repeatedly employed in Mizoroki-Heck cross coupling reactions of aryl iodides but turned out not to be recyclable with bromides. Again, the reaction time was $72 \mathrm{~h}$ for the coupling of $p$-bromoacetophenone with styrene. ${ }^{13}$ Polymer-supported phosphapalladate 5 shows catalytic activity in Sonogashira reactions in the presence of $\mathrm{CuI}$ under argon atmosphere. ${ }^{14}$ Similar results were obtained with silica-supported catalyst $\mathbf{6}$. In the absence of $\mathrm{CuI}$ only aryl iodides could be coupled. ${ }^{15,16}$

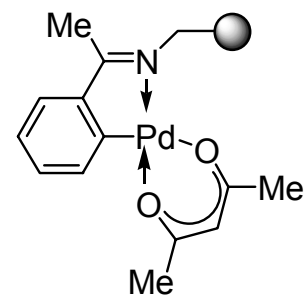

1 (polystyrene)

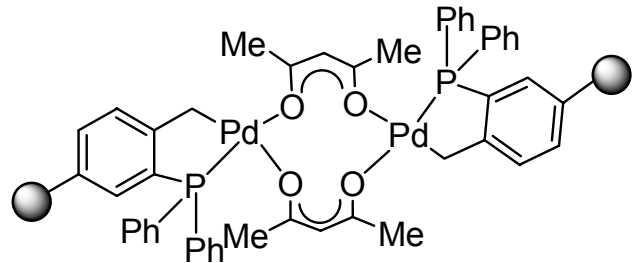

2 (polystyrene)

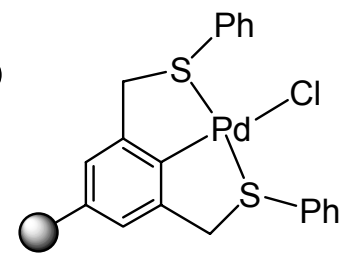

3 (Polyethyleneglycol)<smiles></smiles>

4 (molecular sieves)

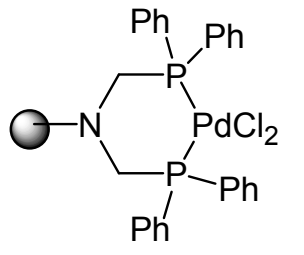

5 (polystyrene)<smiles>O=CCN1CP(c2ccccc2)(c2ccccc2)(c2ccccc2)[PH](Cl)(c2ccccc2)C(Cl)(c2ccccc2)P1</smiles>

$6\left(\mathrm{SiO}_{2}\right)$

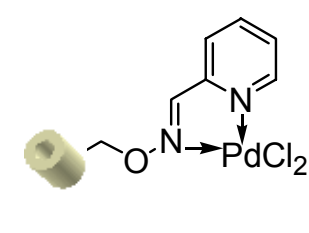

7 (polystyrene on glass/polymer composite material)

Figure 1. Selected immobilized palladacycles. 
Recently, we reported on the heterogeneous Pd-precatalyst 7 anchored to a polystyrene phase which is part of a highly megaporous glass/polymer composite matrix shaped as Raschig rings. It turned out to be a highly active and recyclable catalytic system for Suzuki-Miyaura cross coupling reactions in water. ${ }^{5}$ As a continuation of this work, we evaluated palladium(II)precatalyst 7 for its suitability in Mizoroki-Heck and Sonogashira cross coupling reactions under microwave irradiating conditions again using water as solvent. The studies also include the utility of 7 for the preparation of benzo[b]furans from alkynes and ortho-halophenols.

The Mizoroki-Heck reaction has not been extensively studied in aqueous media yet. In one of the first publications on this topic, ligand-free palladium(II) salts were used for the MizorokiHeck reaction in water or in aqueous organic solvents. ${ }^{17}$ Palladium(II) acetate, either employed ligand-free ${ }^{18}$ or in the presence of phosphane ${ }^{19}$ was an appropriate catalyst for the MizorokiHeck reaction under phase-transfer conditions (PTC) in aqueous media. Arylation of styrene in water under PTC was catalyzed by palladium on carbon in the presence of the reducing agent. ${ }^{20}$ Recently, a di-2-pyridylmethylamine- based palladium chloride complex ${ }^{21}$ and a cyclopalladated ferrocenylimine ${ }^{22}$ were shown to be good catalysts for Mizoroki-Heck reactions in water. The $p$ hydroxyacetophenone oxime- derived palladacycle was found to be an efficient catalyst for various Mizoroki-Heck reactions in water under thermal as well as microwave conditions and in the absence of an inert atmosphere. ${ }^{23}$

\section{Results and Discussion}

Mizoroki-Heck reactions under microwave irradiating conditions in water. The possibility of carrying out Mizoroki-Heck cross-coupling reaction in water and under air could be of great importance for the development of industrial processes. ${ }^{2,24,25}$ Therefore, at first, the catalytic activity of the $\mathrm{Pd}(\mathrm{II})$ precatalyst 7 was optimized in the Mizoroki-Heck cross-coupling reaction of 4-bromoacetophenone $\mathbf{8}$ with tert-butyl acrylate 9 (Table 1). The reaction was carried out in water, dimethylformamide or acetonitrile as solvents using different bases (e.g. $\mathrm{NEt}_{3}, i \mathrm{Pr}_{2} \mathrm{NH}$, $\mathrm{NaOAc}, \mathrm{K}_{2} \mathrm{CO}_{3}, \mathrm{NaOH}$ and $\left.\mathrm{KOH}\right)$. Among the solvents tested, water gave the best results $(100 \%$ conversion) in the presence of either $\mathrm{NaOH}$ or $i \operatorname{Pr}_{2} \mathrm{NH}$ as bases. Under the same conditions, the other bases $\mathrm{Et}_{3} \mathrm{~N}, \mathrm{~K}_{2} \mathrm{CO}_{3}, \mathrm{NaOAc}$ and $\mathrm{KOH}$ gave $29 \%, 49 \%, 5 \%$ and $67 \%$ conversions, respectively. The use of DMF with either $\mathrm{NaOH}$ or $i \mathrm{Pr}_{2} \mathrm{NH}$ as bases also afforded full conversions $(100 \%)$. Thus, treatment of 4-bromoacetophenone 8 (1 mmol) with tert-butyl acrylate $9(1.5 \mathrm{mmol})$ in water $(3 \mathrm{~mL})$ at $100^{\circ} \mathrm{C}$ for $7 \mathrm{~h}$ in the presence of tetrabutylammonium bromide $(0.5 \mathrm{mmol})$, di-isopropylamine $(3 \mathrm{mmol})$ and the Pd-precatalyst $7(0.7 \mathrm{~mol} . \%$, i.e. a quarter piece of one Raschig ring that was loaded with about 2.8 mol.\% palladium with reference of $1 \mathrm{mmol}$ scaled reactions) resulted in quantitative formation of tert-butyl $p$-acetylcinnamate $\mathbf{1 0}$. Not surprisingly, water was found to be superior to DMF as solvent as far as reusability of the catalytic system was concerned. In DMF complex 7 lost its catalytic activity soon after the first run while in water deactivation was observed after the third run under thermal heating. However, 
under microwave irradiating conditions precatalyst 7 became inactive after the first run both in water and DMF. This observation is in sharp contrast to our findings for Suzuki-Miyaura reaction with the same heterogeneous system. ${ }^{5}$ In the latter case, precatalyst 7 could be reused both under thermal as well as microwave irradiating conditions for at least ten consecutive runs. However, microwave irradiating conditions greatly facilitates to reduce the reaction time for the solid-phase assisted catalytic C-C coupling reaction but it appears that this is achieved for the price of more rapid deactivation of the catalytic system. Additionally, we altered the loading of the Pd-complex on the glass/polymer composite material and studied its influence on the outcome of the Mizoroki-Heck reaction (Table 1).

Table 1. Reusability of the Pd-precatalyst in a Mizoroki-Heck model reaction

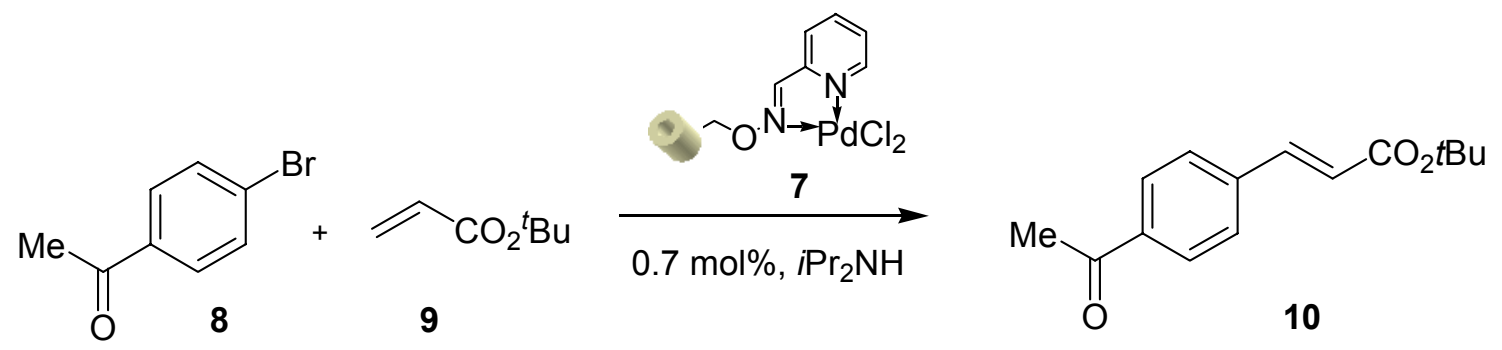

\begin{tabular}{l|llll}
\hline \multirow{2}{*}{ Run } & \multicolumn{2}{|c}{ Thermal heating $^{a, \mathrm{~b}}$} & \multicolumn{2}{l}{$\mu$ Heating ${ }^{\mathrm{a}, \mathrm{b}}$} \\
& Water & DMF & Water & DMF \\
\hline High loading $^{\mathrm{c}}$ & & & & \\
1 & 100 & 100 & 100 & 100 \\
2 & 88 & 38 & $<1$ & -- \\
3 & 23 & -- & & \\
Low loading $^{\mathrm{d}}$ & & & & \\
1 & 64 & 100 & 96 & 100 \\
2 & 6 & $<1$ & $<1$ & -- \\
\hline
\end{tabular}

${ }^{\text {a }}$ Conditions: Bromide/olefin $/ i-\mathrm{Pr}_{2} \mathrm{NH} / \mathrm{TBAB}=1 / 1.5 / 3 / 0.6$, solvent $(3 \mathrm{ml}), 7(0.7 \mathrm{~mol} . \%), 100^{\circ} \mathrm{C}$ for thermal heating and $150^{\circ} \mathrm{C}(200 \mathrm{watt})$ for $\mu \mathrm{w}$ heating in water; $130^{\circ} \mathrm{C}$ for thermal heating and $150^{\circ} \mathrm{C}$ (200 watt) for $\mu \mathrm{w}$ irradiation in DMF. TBAB was only used when water was used as solvent. ${ }^{\mathrm{b}}$ GC-yields in \%. ${ }^{\mathrm{c}}$ High Pd content (0.09 mmol 7 per g Raschig rings). ${ }^{\mathrm{d}}$ Low Pd content (loading was carried out with one tenth of Pd complex which equals $0.01 \mathrm{mmol} 7$ per $\mathrm{g}$ Raschig rings).

The rationale for this study is associated with the fact that there has been much debate on the catalytically active species that is operating in $\mathrm{C}-\mathrm{C}$ coupling reactions when $\mathrm{Pd}(\mathrm{II})$ palladacycles are employed. Complexes that are listed in Figure 1 may serve as "dormant species" 9 a that are not involved in the real catalytic cycle but are a source of coordinative unsaturated " $\mathrm{PdL}_{\mathrm{n}}$ " species of unknown nature or release a considerable amount of colloidal 
$\operatorname{Pd}(0)$ which also can show catalytic activity at low concentrations as was shown for MizorokiHeck reactions. ${ }^{10,12 \mathrm{~d}, 26}$ When $0.1 \mathrm{~mol} . \%$ of 7 (0.01 mmol / g composite material) was employed in the coupling of 4-bromoacetophenone $\mathbf{8}$ with tert-butyl acrylate $\mathbf{9}$ conversion was determined to be $93 \%$ which favorably compares to $56 \%$ for $0.1 \mathrm{~mol} \%$ of precatalyst $7(0.09 \mathrm{mmol} / \mathrm{g}$ composite material. The larger "dilution" of the $\mathrm{Pd}$ source on the polymeric phase may retard the formation and growth of colloids which leads to inactivation.

Studies on the catalytic power of the catalytic system 7 on the rate of conversion under microwave irradiating conditions revealed that, after 5 minutes, full conversion was commonly achieved when 1 mol.\% or 0.7 mol.\%, respectively, of precatalyst 7 was employed. Still, $96 \%$ of conversion was reached using $0.3 \mathrm{~mol} \%$ of 7 . When the molar ratio was further reduced to 0.1 and $0.05 \mathrm{~mol} . \%, 56 \%$ and $12 \%$ of conversions, respectively, were encountered after 5 minutes of $\mu \mathrm{w}$ irradiation using $i \operatorname{Pr}_{2} \mathrm{NH}, \mathrm{TBAB}$ and water as reaction mixture. No $\mathrm{C}-\mathrm{C}$ coupling reaction in the absence of 7 even in the presence of tetrabutylammonium bromide under thermal as well microwave heating conditions was detected by GC. The presence of tetrabutylammonium bromide (TBAB) is essential for carrying out Mizoroki-Heck cross-coupling of aryl chlorides and aryl bromides. ${ }^{27}$ Indeed, in the absence of TBAB conversion went down to $43 \%$ (for diisopropylamine as base) and $4 \%$ (for $\mathrm{NaOH}$ as base), respectively, in water, when conventional heating was employed. Microwave irradiation in the absence of TBAB using $0.7 \mathrm{~mol} \%$ of Pdprecatalyst 7 resulted in full conversion of 4-bromoacetophenone $\mathbf{8}$ into the cinnamate ester $\mathbf{1 0}$ when di-isopropylamine was used as base while with $\mathrm{NaOH}$ only $6 \%$ of the coupling product 10 was formed. These results may be attributed to the ability of di-isopropylamine to react with the hydrogen halide generated during the reaction to quaternary ammonium salts formed in situ. This salt may then fulfill a similar role as $\mathrm{TBAB}$ which cannot be generated when an inorganic base such as $\mathrm{NaOH}$ is used.

In the following we employed the optimized conditions for carrying out Mizoroki-Heck reactions with heterocyclic bromides and tert-butyl acrylate 9 (Table 2). Again, in all cases, water was found to be superior to DMF under both conventional as well as $\mu \mathrm{w}$ irradiating conditions. In cases where prolonged reaction times are required under $\mu \mathrm{w}$ conditions, conventional heating is preferable (entries 4 and 6, Table 2). This may reflect the lack of stability of the palladium precatalyst 7 under $\mu \mathrm{w}$ irradiating conditions.

Interestingly, the cross-coupling reaction of aryl and heteroaryl bromides was highly regioand stereoselective and provided only the thermodynamically more stable $E$-isomer of $\beta$ substituted tert-butyl acrylates where GC, GC-MS and ${ }^{1} \mathrm{H}$ NMR-spectra of the crude reaction mixture did not reveal any evidence for $\alpha$-arylation or the formation of $Z$-isomers. In addition, we also did not encounter the formation of carboxylic acids in the crude products which would have originated from ester hydrolysis under the basic conditions. 
Table 2. Mizoroki-Heck reaction of heterocyclic bromides with tert-butyl acrylate, $\mathbf{8}$

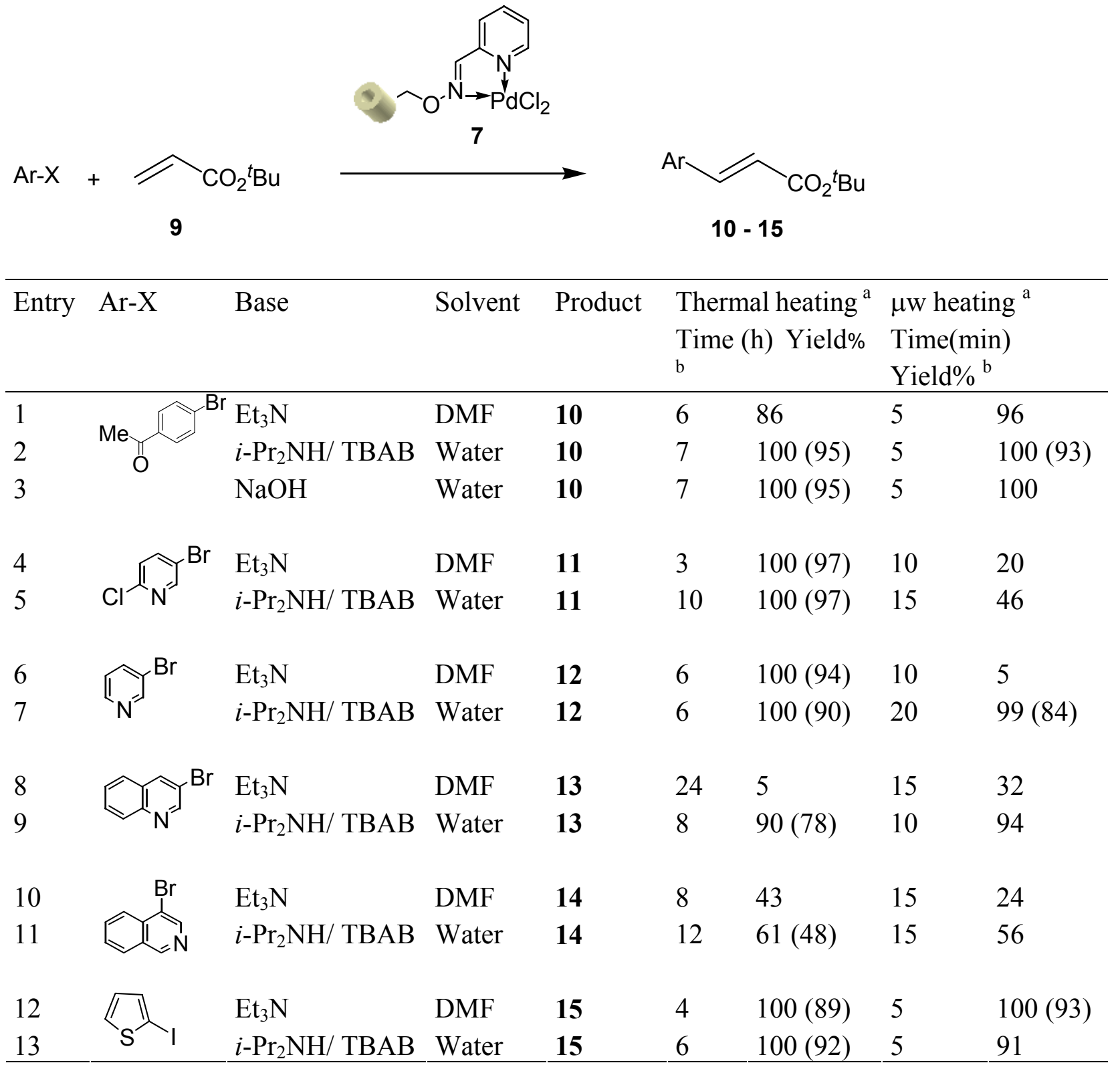

${ }^{a}$ Conditions: Halide/olefin/base/TBAB $=1 / 1.5 / 3 / 0.6, \mathrm{DMF}$ or water $(3.5 \mathrm{ml})$, Pd-precatalyst 7 $(0.7 \mathrm{~mol} \%), 100^{\circ} \mathrm{C}$ (water) or $130^{\circ} \mathrm{C}(\mathrm{DMF})$ for thermal heating; $150^{\circ} \mathrm{C}$ (200 watt) for $\mu \mathrm{w}$ heating. ${ }^{\mathrm{b}} \mathrm{GC}$-yields; values in parentheses refer to isolated yields of pure products. 
Table 3. Mizoroki-Heck reactions of heterocyclic halides with styrene, 16

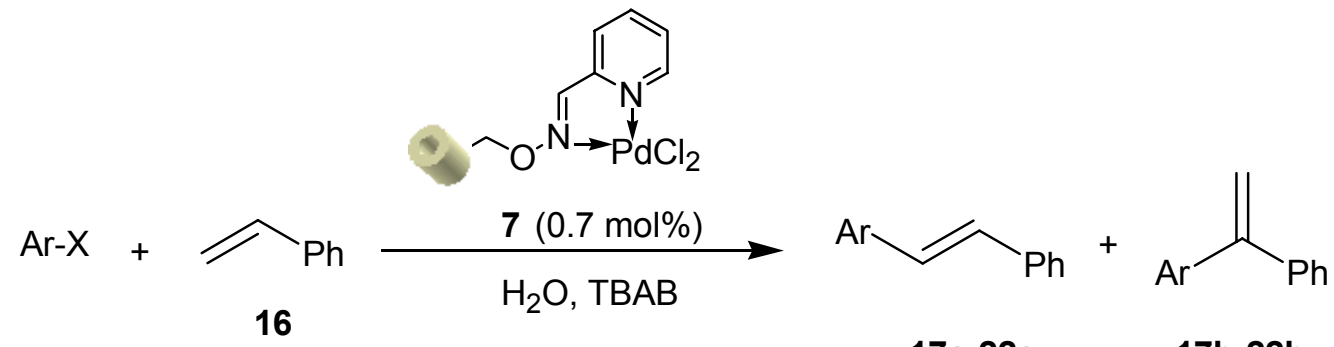

$17 a-22 a \quad 17 b-22 b$

\begin{tabular}{|c|c|c|c|c|c|c|c|c|c|}
\hline \multirow[t]{2}{*}{ Entry } & \multirow[t]{2}{*}{ Ar-X } & \multirow[t]{2}{*}{ Base } & \multirow[t]{2}{*}{ Products } & \multicolumn{3}{|c|}{ Thermal heating a } & \multicolumn{3}{|c|}{$\mu w$ heating $^{\text {a }}$} \\
\hline & & & & $\mathrm{T}(\mathrm{h})$ & a $\%^{b} \quad$ & b $\%{ }^{b}$ & $\mathrm{t}(\min )$. & a $\%{ }^{b}$ & b $\%{ }^{b}$ \\
\hline 1 & & $i-\mathrm{Pr}_{2} \mathrm{NH}$ & $17 \mathbf{a}, \mathbf{b}$ & 15 & $58^{\mathrm{c}}$ & 2 & 15 & $90(89)^{\mathrm{d}}$ & 10 \\
\hline 2 & & $\mathrm{NaOH}$ & $17 \mathbf{a}, \mathbf{b}$ & 5 & $98(92)$ & 2 & 5 & $97(94)$ & 3 \\
\hline 3 & & $i-\mathrm{Pr}_{2} \mathrm{NH}$ & $18 a, b$ & 15 & 34 & 1 & 15 & $90(89)$ & $10^{\mathrm{e}}$ \\
\hline 4 & & $\mathrm{NaOH}$ & $18 a, b$ & 15 & $97(95)$ & 3 & 10 & $97(92)$ & 3 \\
\hline 5 & & $i-\mathrm{Pr}_{2} \mathrm{NH}$ & $19 a, b$ & 15 & 38 & 2 & 15 & 90 & 10 \\
\hline 6 & & $\mathrm{NaOH}$ & $19 a, b$ & 15 & $96(89)$ & 4 & 10 & $91(90)$ & 9 \\
\hline 7 & & $i-\mathrm{Pr}_{2} \mathrm{NH}$ & 20a,b & 15 & 60 & 4 & 15 & $90(89)$ & $10(7)$ \\
\hline 8 & & $\mathrm{NaOH}$ & $20 \mathbf{a}, \mathbf{b}$ & 12 & $97(91)$ & 3 & 15 & $92(85)$ & 8 \\
\hline 9 & & $i-\mathrm{Pr}_{2} \mathrm{NH}$ & $21 \mathbf{a}, \mathbf{b}$ & 20 & 21 & 2 & 5 & $84(78)$ & $16(13)$ \\
\hline 10 & & $\mathrm{NaOH}$ & 21a,b & 8 & 78 & 2 & 15 & 89 & 10 \\
\hline 11 & & $i-\mathrm{Pr}_{2} \mathrm{NH}$ & $22 a, b$ & 6 & $95(91)$ & 5 & 10 & $92(87)$ & 8 \\
\hline 12 & & $\mathrm{NaOH}$ & $22 a, b$ & 5 & 92 & 8 & 7 & 91 & 9 \\
\hline
\end{tabular}

${ }^{a}$ Conditions: Halide/olefin/base/TBAB $=1 / 1.5 / 3 / 0.6$, water $(3 \mathrm{ml}), 7(0.7 \mathrm{~mol} . \%), 100^{\circ} \mathrm{C}$ for thermal heating and $160^{\circ} \mathrm{C}\left(250\right.$ watt) for $\mu \mathrm{w}$ heating. ${ }^{\mathrm{b}} \mathrm{GC}$-yields; values in parentheses refer to isolated yields of pure products. ${ }^{\mathrm{c}} 100 \%$ (GC) after $5 \mathrm{~h}$ when $2.8 \mathrm{~mol} \%$ of precatalyst 7 was employed. ${ }^{\mathrm{d}} 94 \%$ (GC) after 5 minutes when 2.8 mol.\% of precatalyst 7 was employed; $76 \%$ (GC) after 5 minutes when 0.7 mol.\% of precatalyst 7 was employed. ${ }^{\mathrm{e}} \mathbf{1 8 b}$ was isolated in minute amounts, so that analysis was only based on ${ }^{1} \mathrm{H}$ NMR spectroscopy and MS.

Although both water $/ \mathrm{NaOH}$ as well as water $/ i-\operatorname{Pr}_{2} \mathrm{NH}$ gave best results in the cross coupling reaction of active tert-butyl acrylate 9 with 4-bromoacetophenone $\mathbf{8}$, the reaction mixture water $/ i$ - $\mathrm{Pr}_{2} \mathrm{NH}$ did not give the expected results under conventional heating conditions in related Mizoroki-Heck reactions with less reactive styrene 16. However, full conversion was 
achieved under $\mu \mathrm{w}$ irradiating conditions (entry 1, Table 3). Similar observations were noticed for Mizoroki-Heck reactions with all other heteroaryl bromides with styrene (entries 3, 5, 7 and 9, Table 3). However, similar Mizoroki-Heck reaction of the highly reactive 2-iodothiophene with styrene using either water $/ \mathrm{NaOH}$ or water $/ i \mathrm{Pr}_{2} \mathrm{NH}$ furnished full conversion under both thermal as well as $\mu \mathrm{w}$ irradiating conditions (entries 11 and 12, Table 3 ). In each case, GC, GCMS and ${ }^{1} \mathrm{H}$ NMR-spectroscopy of the crude reaction mixture confirmed the formation of two isomeric products. The ratio of the two isomers $\mathbf{1 7 a}, \mathbf{b}-\mathbf{2 2 a}, \mathbf{b}$ was about 20:1 under thermal conditions and about 12:1 under $\mu \mathrm{w}$ irradiating conditions. The major products were the $E$ isomers of 1,2-disubstituted alkenes $\mathbf{1 7 a - 2 2 a}$ while the minor byproducts were clearly not the $Z$ -

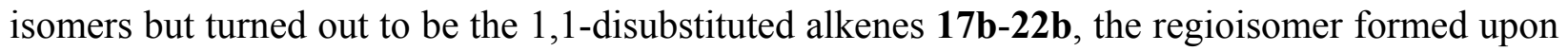
$\alpha$-arylation. ${ }^{28}$ The ${ }^{1} \mathrm{H}-,{ }^{13} \mathrm{C}$ - and HMQC spectra of compound $\mathbf{2 1 b}$ (as a selected example) confirmed the formation of the 1,1-disubstituted ethylene structure and ruled out the alternative $Z$-isomer.

\section{Sonogashira reactions under microwave irradiating conditions in water}

Commonly, Sonogashira cross-coupling reactions are carried out under inert atmosphere using degassed organic solvents and phosphine ligands in the presence of a copper(I) source. ${ }^{29,30}$ Additionally, organic solvents are usually employed which can serve as good ligands for palladium particles, which may remove palladium from the solid phase into solution. By keeping those obstacles in mind we extended our studies on the catalytic activity of the heterogeneous palladium precatalyst 7 on Sonogashira cross coupling reactions of aryl and heteroaryl bromides with phenylacetylene under aqueous copper- and phosphine- free conditions in air. Under phosphine- and copper free conditions in water as solvent and di-isopropylamine as base the cross coupling of phenyl acetylene 23 with 4-iodoacetophenone using precatalyst 7 afforded diaryl acetylene $\mathbf{2 4}$ both under thermal as well as $\mu \mathrm{w}$ irradiating conditions (entries 1 and 2, Table 4). With 4-bromoacetophenone the conversion to the desired diaryl acetylene $\mathbf{2 4}$ was inefficient irrespective of the mode heating applied. Only when sodium hydroxide served as base full conversion for this reaction was encountered (entry 4, Table 4). 
Table 4. Sonogashira reaction under thermal and $\mu \mathrm{w}$ conditions in water

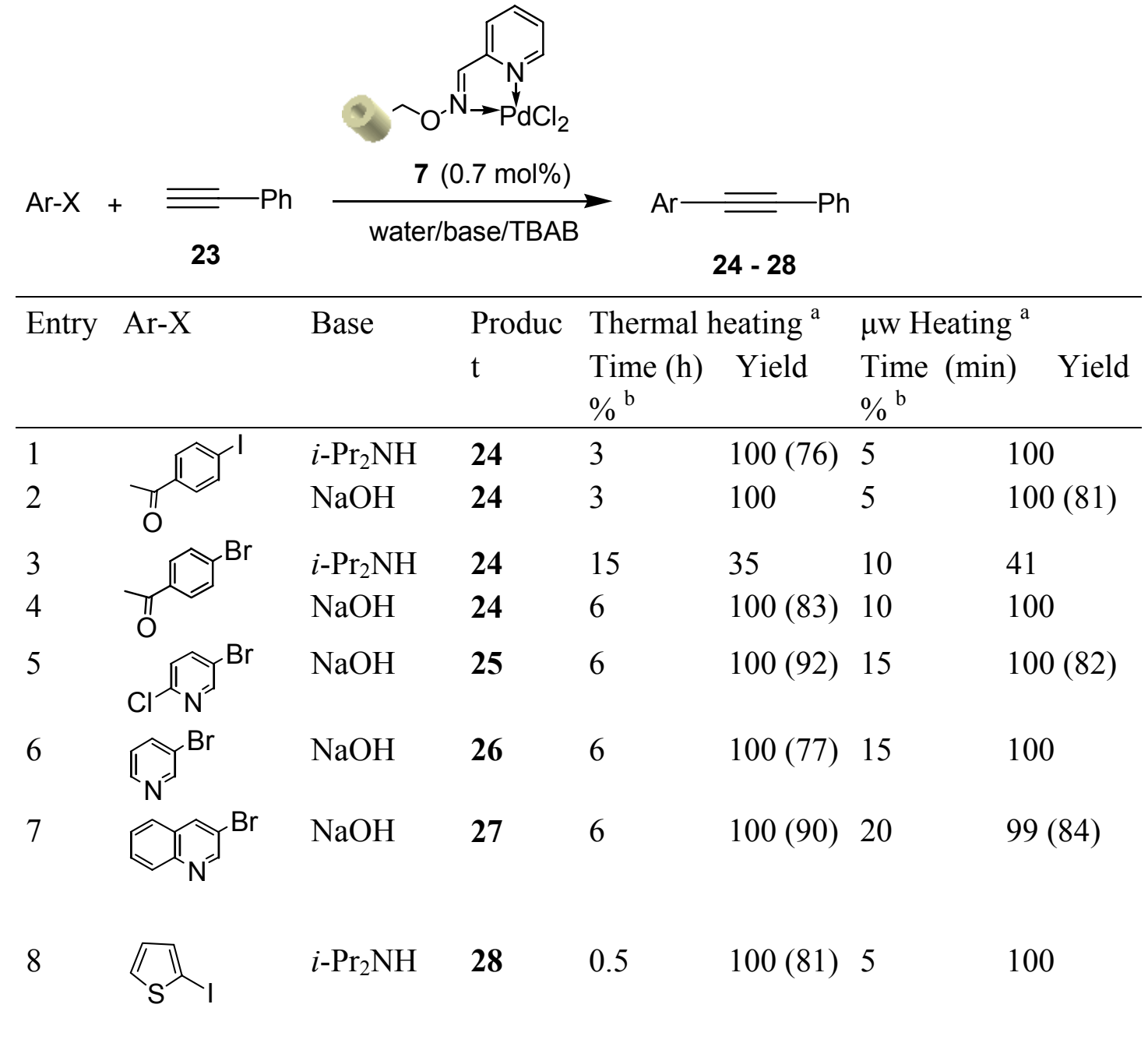

\footnotetext{
${ }^{\mathrm{a}}$ Conditions: Halide/acetylene/base/TBAB $=1 / 1.5 / 3 / 0.6$, water $(2.5 \mathrm{ml}), 7(0.7 \mathrm{~mol} . \%), 100^{\circ} \mathrm{C}$ for thermal heating and $160^{\circ} \mathrm{C}\left(250\right.$ watt) for $\mu \mathrm{w}$ heating. ${ }^{\mathrm{b}} \mathrm{GC}$-yields; values in parentheses refer to isolated yields of pure products.
}

Interestingly, the cross-coupling of phenylacetylene $\mathbf{2 3}$ with heteroaryl bromides (entries 5-7, Table 4) in water in the presence of sodium hydroxide afforded the corresponding aryl heteroaryl acetylenes 25-28 in high isolated yields with full conversions regardless which mode of heating technique was employed. In addition, we found that the Sonogashira coupling of 2iodothiophene with phenylacetylene $\mathbf{2 3}$ is remarkably facile $(30 \mathrm{~min})$ in comparison to alternate solid phase examples from the literature which commonly require $72 \mathrm{~h} .{ }^{11}$ Therefore, we decided to study the recyclability of the precatalyst 7 under thermal conditions. Thus, treatment of 2iodothiophene with phenylacetylene $\mathbf{2 3}$ and di-isopropylamine in water in the presence of freshly prepared precatalyst $7(0.7 \mathrm{~mol} . \%)$ at $100^{\circ} \mathrm{C}$ for 30 minutes furnished the (2thienyl)phenylacetylene 28 (100\% conversion; 81\% isolated yield). Bannwarth and co-workers ${ }^{31}$ 
reported that a perfluorinated Pd-complex was completely poisoned by the thiophene moiety after the first run of cross coupling 3-thienylboronic acid with aryl bromides. However, we could find that our Pd-precatalyst 7 was recyclable for at least five consecutive Sonogashira coupling reactions of 2-iodothiophene with phenylacetylene $\mathbf{2 3}$ (Table 5).

Table 5. Recyclability of precatalyst 7 in the Sonogashira reaction of 2-iodothiophene.

$\begin{array}{lll} & & \\ & & 23 \\ \end{array}$

Conditions: Iodide $/ \mathbf{2 3} / i-\mathrm{Pr}_{2} \mathrm{NH} / \mathrm{TBAB}=1 / 1.5 / 3 / 0.6$, water $(2.5 \mathrm{ml}), 7\left(0.7 \mathrm{~mol} \%\right.$ ), $100^{\circ} \mathrm{C}$. GCyields; values in parenthesis refer to isolated yield of pure $\mathbf{2 8}$.

Benzo $[b]$ furan derivatives are of relevance because of their natural occurrence ${ }^{32}$ associated with their biological properties. ${ }^{33}$ The reaction of $o$-halophenols with terminal alkynes in the presence of $\mathrm{Pd}$ and/or $\mathrm{Cu}$ catalysts provides a common and direct route to benzofurans. ${ }^{34}$ In most cases, homogeneous palladium catalysts were employed in the presence of copper(I) iodide, phosphine ligands and DMF or acetonitrile as solvents under inert atmosphere. ${ }^{35,36}$ Addition of copper salt is particularly inconvenient because the use of copper usually leads to contamination of the products and by-products formed through Glaser-type reactions. We expected that our polymer-bound $\mathrm{Pd}(\mathrm{II})$ complex 7 can serve as an active, recyclable, and stable precatalyst for the copper- and phosphine-free Sonogashira based synthesis of benzofuran derivatives, a real improvement to reported procedures.

Thus, treatment of a mixture of 2-iodophenol 29 (1 equiv), phenylacetylene 23 ( 2 equiv), di-iso-propylamine ( 3 equiv) and TBAB (0.6 equiv) with precatalyst 7 in water as solvent (2.5 $\mathrm{mL}$ ) at $100^{\circ} \mathrm{C}$ under air, resulted in full conversion to 2-phenylbenzo[b]furan 32. Although in acetonitrile also full conversion was encountered for the first run (entry 4, Table 6), it turned out that the second run with the same catalytic sample only yielded the target furan 32 in $62 \%$ (entry 5, Table 6) which can be ascribed to the good coordinating properties of acetonitrile compared to water, thus dissolving a palladium species of unknown nature from its solid support into solution. 
Precatalyst 7 could be recycled three times with full conversions when water was utilized as solvent (entries 7-9, Table 6). In contrast, when tributylamine was used as base in acetonitrile as solvent (entry 3, Table 6) or di-iso-propylamine in THF (entry 6, Table 6) the C-C coupling only proceeded inefficiently. The less reactive 2-bromophenol $\mathbf{3 0}$ also coupled with phenylacetylene 23 to give 2-phenylbenzo[b] furan 32, however conversion did not exceed $17 \%$ conversion in acetonitrile as solvent (entry 10) while complete conversion occurred in water using either diiso-propylamine or sodium hydroxide as base (entries 11 and 12, Table 6). High chemoselectivity was observed in the cross coupling of 2-bromo-4-chlorophenol 31 with phenylacetylene $\mathbf{2 3}$ to give 5-chloro-2-phenylbenzo[b]furan $\mathbf{3 3}$ again with full conversion (entry 13, Table 6).

In conclusion, we have demonstrated that the Pd-complex 7 is an efficient and highly active, reusable solid-phase anchored precatalyst with good potential for Mizoroki-Heck and Sonogashira cross-coupling reactions in aqueous media. Importantly, it not only shows activity under thermal but also under microwave irradiating conditions. In contrast to applications in Suzuki-Miyaura reactions, ${ }^{5}$ precatalyst 7 cannot be employed in Mizoroki-Heck and Sonogashira cross-coupling reactions with aryl chlorides as substrates.

Table 6. Synthesis of benzo[b]furan derivatives via Sonogashira cross coupling reaction. ${ }^{\text {a }}$

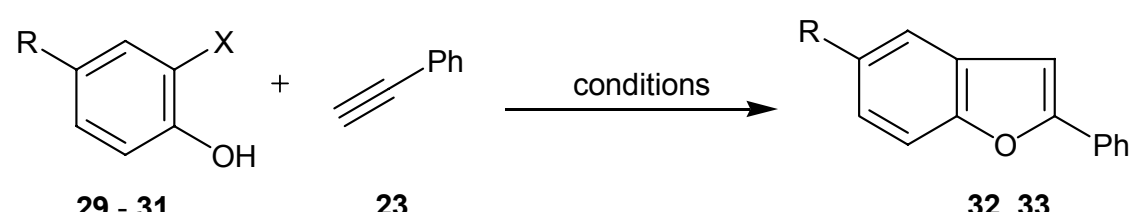

\begin{tabular}{llllllll}
\hline Entry & $\mathrm{R}$ & $\mathrm{X}$ & Base & Product & Solvent & $\begin{array}{l}\text { Time } \\
(\mathrm{h})\end{array}$ & Yield \% \\
\hline 1 & $\mathrm{H}$ & $\mathrm{I}$ & $\mathrm{Et}_{3} \mathrm{~N}$ & $\mathbf{3 2}$ & $\mathrm{DMF}$ & 4 & 59 \\
2 & $\mathrm{H}$ & $\mathrm{I}$ & $\mathrm{Et}_{3} \mathrm{~N}$ & $\mathbf{3 2}$ & $\mathrm{CH}_{3} \mathrm{CN}$ & 6 & 90 \\
3 & $\mathrm{H}$ & $\mathrm{I}$ & $\mathrm{Bu}_{3} \mathrm{~N}$ & $\mathbf{3 2}$ & $\mathrm{CH}_{3} \mathrm{CN}$ & 22 & 23 \\
4 & $\mathrm{H}$ & $\mathrm{I}$ & $i-\mathrm{Pr}_{2} \mathrm{NH} / \mathrm{TBAB}$ & $\mathbf{3 2}$ & $\mathrm{CH}_{3} \mathrm{CN}$ & 8 & $100(80)\left(1^{\text {st }}\right.$ run $)$ \\
5 & $\mathrm{H}$ & $\mathrm{I}$ & $i-\mathrm{Pr}_{2} \mathrm{NH} / \mathrm{TBAB}$ & $\mathbf{3 2}$ & $\mathrm{CH}_{3} \mathrm{CN}$ & 6 & $62\left(2^{\text {nd }}\right.$ run $)$ \\
6 & $\mathrm{H}$ & $\mathrm{I}$ & $i-\mathrm{Pr}_{2} \mathrm{NH} / \mathrm{TBAB}$ & $\mathbf{3 2}$ & $\mathrm{THF}$ & 16 & 4 \\
7 & $\mathrm{H}$ & $\mathrm{I}$ & $i-\mathrm{Pr}_{2} \mathrm{NH} / \mathrm{TBAB}$ & $\mathbf{3 2}$ & water & 3 & $100(76)\left(1^{\text {st }}\right.$ run $)$ \\
8 & $\mathrm{H}$ & $\mathrm{I}$ & $i-\mathrm{Pr}_{2} \mathrm{NH} / \mathrm{TBAB}$ & $\mathbf{3 2}$ & water & 3 & $100\left(2^{\text {nd }}\right.$ run $)$ \\
9 & $\mathrm{H}$ & $\mathrm{I}$ & $i-\mathrm{Pr}_{2} \mathrm{NH} / \mathrm{TBAB}$ & $\mathbf{3 2}$ & water & 10 & $100\left(3^{\text {rd }}\right.$ run $)$ \\
10 & $\mathrm{H}$ & $\mathrm{Br}$ & $i-\mathrm{Pr}_{2} \mathrm{NH} / \mathrm{TBAB}$ & $\mathbf{3 2}$ & $\mathrm{CH}_{3} \mathrm{CN}$ & 16 & 17 \\
11 & $\mathrm{H}$ & $\mathrm{Br}$ & $i-\mathrm{Pr}_{2} \mathrm{NH} / \mathrm{TBAB}$ & $\mathbf{3 2}$ & water & 8 & 100 \\
12 & $\mathrm{H}$ & $\mathrm{Br}$ & $\mathrm{NaOH}^{2} \mathrm{TBAB}$ & $\mathbf{3 2}$ & water & 7 & 100 \\
13 & $\mathrm{Cl}$ & $\mathrm{Br}$ & $\mathrm{NaOH}^{2} \mathrm{TBAB}$ & $\mathbf{3 3}$ & water & 7 & $100(73)$ \\
\hline
\end{tabular}

${ }^{a}$ Conditions: Halide/acetylene/base/TBAB = 1/1.5/3/0.6, solvent (2.5 ml), 7 (0.7 mol. \%); GCyields; values in parentheses refer to isolated yields of pure products. 


\section{Experimental Section}

General Procedures. NMR spectra were recorded with a Bruker DPX-400 spectrometer at 400 $\mathrm{MHz}\left({ }^{1} \mathrm{H}\right.$ NMR) and at $100 \mathrm{MHz}\left({ }^{13} \mathrm{C} \mathrm{NMR}\right)$ using $\mathrm{CDCl}_{3}$ as solvent and internal standard $(\delta=$ 7.26 and $77.36 \mathrm{ppm}$, for ${ }^{1} \mathrm{H} \mathrm{NMR}$ and ${ }^{13} \mathrm{C}$ NMR, respectively). Mass spectra (EI) were obtained at $70 \mathrm{eV}$ with a type VG Autospec apparatus (Micromass). GC Analyses were conducted using a Hewlett Packard HPGC series 6890 Series equipped with an SE-54 capillary column (25 m, Macherey-Nagel) and an FID detector 19231 D/ E. Melting points were determined in open glass capillaries with a Gallenkamp apparatus and are uncorrected. Analytical thin-layer chromatography was performed using precoated silica gel 60 F254 plates (Merck, Darmstadt), and the spots were visualized with UV light at $254 \mathrm{~nm}$. Merck silica gel 60 (230-400 mesh) was used for flash column chromatography. Microwave experiments were carried out using a CEM Discover Labmate $^{\mathrm{TM}}$ microwave apparatus $\left(300 \mathrm{~W}\right.$ with ChemDriver $^{\mathrm{TM}}$ Software). Commercially available reagents and dry solvents were used as received.

Preparation of Pd-precatalyst 7 (high loading). To a mixture of glass/polymer composite material shaped as Raschig rings (10 g, $5 \mathrm{mmol}$ ) containing about 10\% chloromethylpolystyrenedivinylbenzene polymer $(0.53 \mathrm{mmol}$ of active benzyl chloride sites on polymer/g Raschig rings) and cis-2-pyridinealdoxime (3.66 g, $30 \mathrm{mmol})$ in dimethylformamide (DMF) (50 mL), was added sodium hydride $(0.72 \mathrm{~g}, 60 \%$ in oil, $30 \mathrm{mmol})$ portionwise over a period of $20 \mathrm{~min}$. The mixture was shaken at $80^{\circ} \mathrm{C}$ for three days then cooled to room temperature and quenched with water $(100 \mathrm{~mL})$. The Raschig rings were filtered and washed successively with DMF, water, ethanol, dichloromethane and again with ethanol $(20 \mathrm{~mL}$, each time $)$ and finally well-dried under vacuum. These well-dried functionalized Raschig rings 8 (6.92 g) to which cis-2-pyridinealdoxime was bound were added to a solution of sodium tetrachloropalladate $(1.2 \mathrm{~g}, 4 \mathrm{mmol})$ in methanol $(80 \mathrm{~mL})$ and the mixture was shaken at room temperature for additional three days. The resulting Raschig rings were dried in vacuo and the loading of catalyst 7 was estimated to be ca. $0.09 \mathrm{mmol} / \mathrm{g}$ Raschig rings according to weight increase (the weight increase of each single Raschig ring was determined; each ring was loaded with about 2.8 mol.\% palladium with reference of $1 \mathrm{mmol}$ scale for the reaction).

Preparation of Pd-precatalyst 7 (low loading). A similar procedure as described above for the preparation of Pd-precatalyst (high loading) was employed, using 0.1 equivalent of all ingredients for the same number of Raschig rings used above.

General procedure for the Mizoroki-Heck coupling of aryl(heteroaryl) bromides with thermal heating. A mixture of the appropriate aryl or heteroaryl bromide $(1 \mathrm{mmol})$ and the appropriate olefin $(1.5 \mathrm{mmol})$, TBAB $(0.6 \mathrm{mmol})$, precatalyst 7 (high loading; $0.7 \mathrm{~mol} \%$, one quarter of a full Raschig ring), and diisopropylamine or sodium hydroxide (3 mmol) in water or $\mathrm{DMF}\left(3 \mathrm{~mL}\right.$ ) was shaken at $100^{\circ} \mathrm{C}$ (for water as solvent) or at $130^{\circ} \mathrm{C}$ (for DMF as solvent) under air for the given reaction time listed in Table 1. After the reaction was completed (monitored by GC), the reaction mixture was cooled to room temperature and the solid catalyst was removed by filtration, washed with water followed by ethyl acetate, and the combined washings were added 
to the filtrate which was then extracted with ethyl acetate $(3 \times 20 \mathrm{~mL})$. The products were purified by flash column chromatography on silica gel using ethyl acetate/ petroleum ether $=1: 10$ as eluent.

General procedure for the Mizoroki-Heck coupling of aryl(heteroaryl) bromides under $\mu w$ irradiating conditions. A mixture of the appropriate aryl or heteroaryl bromide $(1 \mathrm{mmol})$ and the appropriate olefin $(1.5 \mathrm{mmol})$, TBAB $(0.6 \mathrm{mmol})$, precatalyst 7 (high loading; $0.7 \mathrm{~mol} \%$, one quarter of a complete Raschig ring), and diisopropylamine or sodium hydroxide ( $3 \mathrm{mmol}$ ) in water or DMF (3 $\mathrm{mL})$ were mixed in a process vial. The vial was capped properly, and thereafter the mixture was heated under $\mu \mathrm{w}$ irradiating conditions at $150^{\circ} \mathrm{C}$ and $200 \mathrm{watt}$ in either solvent for the appropriate reaction time as listed in Tables 1 and 2. The products were purified as described above.

Effect of concentration of the palladium precatalyst 7 on the Mizoroki-Heck coupling in water under $\mu \mathrm{w}$ irradiating conditions. A mixture of $p$-bromoacetophenone $(1 \mathrm{mmol})$, tertbutyl acrylate $(1.5 \mathrm{mmol})$, TBAB $(0.6 \mathrm{mmol})$, precatalyst 7 (high loading; $1 \mathrm{~mol} \%$ ), disopropylamine $(3 \mathrm{mmol})$ and water $(3 \mathrm{~mL})$ was heated under $\mu \mathrm{w}$ irradiating conditions at 150 ${ }^{\circ} \mathrm{C}$ (200 watt) for 5 minutes. The same experiment was repeated using 1 mmole of $p$ bromoacetophenone and the amount (mol.\%) of the palladium precatalyst 7 was changed to 0.7 , $0.3,0.1$ and 0.05 mol.\%, respectively.

\section{Recycling of the palladium precatalyst 7 in Mizoroki-Heck coupling with thermal heating.} A mixture of $p$-bromoacetophenone $(1 \mathrm{mmol})$, tert-butyl acrylate $(1.5 \mathrm{mmol})$, TBAB $(0.6 \mathrm{mmol})$, precatalyst 7 (high loading; $0.7 \mathrm{~mol} \%$, one quarter of a full Raschig ring), diisopropylamine (3 mmol) and water $(3 \mathrm{~mL})$ was shaken at $100^{\circ} \mathrm{C}$ under air for $7 \mathrm{~h}$ (monitored by GC). The same experiment was conducted using DMF $(3 \mathrm{~mL})$ at $130^{\circ} \mathrm{C}$. After the reaction had went to completion in either solvent (DMF or water), the solid catalyst was removed by filtration, washed with water followed by ethyl acetate, dried and then reused for the following runs with the same molar ratio of components mentioned above. This mixture was shaken again at $100^{\circ} \mathrm{C}$ for $7 \mathrm{~h}$ in water or at $130^{\circ} \mathrm{C}$ in DMF under air for $7 \mathrm{~h}$. This experiment was repeated for another two runs (reaction time, $7 \mathrm{~h}$ for each run), as shown in Scheme 3. The product was purified by flash column chromatography over silica gel using ethyl acetate/ petroleum ether $=1: 10$ as eluent. The same experiment was performed using palladium catalyst 7 (low loading; 0.7 mol.\%, one Raschig ring), in either water or DMF using the same molar ratio of the reaction components and heating condition as mentioned above.

Recycling of the palladium precatalyst 7 in Mizoroki-Heck coupling reaction under $\mu w$ irradiating conditions in water. The same reaction mixture used under thermal conditions was mixed in a properly capped process vial and thereafter the mixture was subjected to $\mu \mathrm{w}$ irradiating conditions at $150^{\circ} \mathrm{C}(200$ watt) in either water or DMF for 5 minutes (monitored by GC) using the high or low loaded palladium precatalyst. The solid phase was removed, washed with water followed by ethyl acetate, dried and then reused for the second run with the same molar ratio of components as listed in Table 2 (irradiating time 5 minutes). 
General procedure for the Sonogashira coupling of aryl(heteroaryl) halides with thermal heating. A mixture of the appropriate aryl or heteroaryl halide $(1 \mathrm{mmol})$ and phenylacetylene (1.5 mmol), TBAB (0.6 mmol), precatalyst 7 (high loading; $0.7 \mathrm{~mol} \%$, one quarter of a full Raschig ring), and diisopropylamine or sodium hydroxide ( $3 \mathrm{mmol})$ in water $(3 \mathrm{~mL})$ was shaken at $100^{\circ} \mathrm{C}$ under air for the time listed in Table 4 until the starting halide was almost consumed (monitored by GC). The reaction mixture was cooled to room temperature and the solid catalyst was removed by filtration, washed with water and ethyl acetate, and the combined washings were added to the filtrate which was then extracted with ethyl acetate $(3 \times 20 \mathrm{~mL})$. The products were purified by flash column chromatography over silica gel using ethyl acetate / petroleum ether $=1: 20$ as eluent.

General procedure for the Sonogashira coupling of aryl(heteroaryl) halides under $\mu w$ irradiating conditions. The same reaction mixture used under thermal conditions was mixed in a properly capped process vial and thereafter the mixture was subjected to microwave irradiating conditions at $160^{\circ} \mathrm{C}(250$ watt) in water for the appropriate reaction time as listed in Table 4 (monitored by GC). The products were purified as described above.

Recycling of the palladium precatalyst 7 in the Sonogashira coupling of 2-iodothiophene with thermal heating. A mixture of 2-iodothiophene $(1 \mathrm{mmol})$, phenylacetylene $(1.5 \mathrm{mmol})$, TBAB (0.6 mmol), precatalyst 7 (high loading; 0.7 mol.\%, one quarter of a complete Raschig ring), diisopropylamine $(3 \mathrm{mmol})$ and water $(3 \mathrm{~mL})$ was shaken at $100^{\circ} \mathrm{C}$ under air for $30 \mathrm{~min}$ (monitored by GC). After the reaction was completed, the solid catalyst was removed by filtration, washed with water followed by ethyl acetate, dried and then reused in a new batch with the same molar ratio of components mentioned above. Then the mixture was shaken again at $100^{\circ} \mathrm{C}$ in water under air for $30 \mathrm{~min}$. This experiment was repeated for five runs (the first three runs for $30 \mathrm{~min}$ and the final two runs for $60 \mathrm{~min}$ ), as shown in Table 5. The product was purified by flash column chromatography over silica gel using ethyl acetate / petroleum ether = $1: 25$ as eluent.

General procedure for the synthesis of 2-phenylbenzo[b]furan with thermal heating. A mixture of the appropriate 2-halophenol $(1 \mathrm{mmol})$ and phenylacetylene $(1.5 \mathrm{mmol})$, TBAB $(0.6$ mmol), precatalyst 7 (high loading; 0.7 mol.\%, one quarter of a full Raschig ring), and the appropriate base $(3 \mathrm{mmol})$ in water, acetonitrile or DMF $\left(2.5 \mathrm{~mL}\right.$ ) was shaken at $100^{\circ} \mathrm{C}$ (for water) at $70^{\circ} \mathrm{C}$ (for acetonitrile) or at $130{ }^{\circ} \mathrm{C}$ (for DMF) under air for the time listed in Table 6. After the reaction was completed (monitored by GC), the reaction mixture was cooled to room temperature and the solid catalyst was removed by filtration, washed with water then ethyl acetate, and the combined washings were added to the filtrate which was then extracted with ethyl acetate $(3 \times 20 \mathrm{~mL})$. The products were purified by flash column chromatography over silica gel using ethyl acetate / petroleum ether $=1: 10$ as eluent.

(E)-tert Butyl 3-(4-acetylphenyl)prop-2-enoate (10). Light yellowish crystals, mp. 99-100 ${ }^{\circ} \mathrm{C}$ (in ref. ${ }^{37}$ no mp. is given); ${ }^{1} \mathrm{H} \mathrm{NMR}\left(\mathrm{CDCl}_{3}\right) \delta 1.54\left(\mathrm{~s}, 9 \mathrm{H}, \mathrm{C}\left(\mathrm{CH}_{3}\right)_{3}\right), 2.61\left(\mathrm{~s}, 3 \mathrm{H}, \mathrm{CH}_{3} \mathrm{CO}\right), 6.46$ $(\mathrm{d}, 1 \mathrm{H}, J=16.04 \mathrm{~Hz}), 7.58(\mathrm{~d}, 1 \mathrm{H}, J=16.04 \mathrm{~Hz}), 7.60(\mathrm{~d}, 2 \mathrm{H}, J=8.52 \mathrm{~Hz}), 7.95(\mathrm{~d}, 2 \mathrm{H}, J=8.52$ 
$\mathrm{Hz}) ;{ }^{13} \mathrm{C} \mathrm{NMR} \delta 26.9,28.3,81.2,123.1,128.3,129.1,138.1,139.4,142.3,166.1,197.6$; MS (m/e) $246\left(\mathrm{M}^{+}\right), 190,175,147,131,102,91,79,57$.

(E)-tert Butyl 3-(2-chloro-5-pyridyl)prop-2-enoate (11). Colorless crystals, mp. 110-111 ${ }^{\circ} \mathrm{C} ;{ }^{1} \mathrm{H}$ NMR $\left(\mathrm{CDCl}_{3}\right) \delta 1.54\left(\mathrm{~s}, 9 \mathrm{H}, \mathrm{C}\left(\mathrm{CH}_{3}\right)_{4}\right), 6.42(\mathrm{~d}, 1 \mathrm{H}, J=16.04 \mathrm{~Hz}), 7.35(\mathrm{~d}, 1 \mathrm{H}, J=8.16 \mathrm{~Hz})$, $7.52(\mathrm{~d}, 1 \mathrm{H}, J=16.04 \mathrm{~Hz}), 7.79(\mathrm{dd}, 1 \mathrm{H}, J=8.2,2.4 \mathrm{~Hz}), 8.49(\mathrm{~d}, 1 \mathrm{H}, J=2.4 \mathrm{~Hz}) ;{ }^{13} \mathrm{C}$ NMR $\delta$ 28.4, 81.4, 123.3, 124.7, 129.7, 136.8, 138.4, 149.6, 152.6, 165.5; MS (m/e) $239\left(\mathrm{M}^{+}\right), 184,166$, $155,138,127,102,92,75,57$. Anal. Calcd for $\mathrm{C}_{12} \mathrm{H}_{14} \mathrm{ClNO}_{2}$ : C, 60.13; H, 5.89; N, 5.84. Found: C, 60.16; H, 5.58; N, 5.80.

(E)-tert Butyl 3-(3-pyridyl)prop-2-enoate (12). Colorless crystals, mp. $57-58^{\circ} \mathrm{C}$ (ref. ${ }^{38} \mathrm{mp}$. $\left.58^{\circ} \mathrm{C}\right) ;{ }^{1} \mathrm{H} \mathrm{NMR}\left(\mathrm{CDCl}_{3}\right) \delta 1.53\left(\mathrm{~s}, 9 \mathrm{H}, \mathrm{C}\left(\mathrm{CH}_{3}\right)_{3}\right), 6.43(\mathrm{~d}, 1 \mathrm{H}, J=16.04 \mathrm{~Hz}), 7.28-7.32(\mathrm{dd}, 1 \mathrm{H}$, $J=7.84,7.84 \mathrm{~Hz}), 7.56(\mathrm{~d}, 1 \mathrm{H}, J=16.04 \mathrm{~Hz}), 7.79-7.82(\mathrm{ddd}, 1 \mathrm{H}, J=7.84,2.02,1.68 \mathrm{~Hz}), 8.57$ $(\mathrm{dd}, 1 \mathrm{H}, J=4.8,1.36 \mathrm{~Hz}), 8.72(\mathrm{~d}, 1 \mathrm{H}, J=2.08 \mathrm{~Hz}) ;{ }^{13} \mathrm{C} \mathrm{NMR} \delta 28.5,81.3,122.7,124.0,130.7$, 134.4, 140.1, 149.9, 151.1, 165.9; MS (m/e) $205\left(\mathrm{M}^{+}\right), 150,132,121,104,93,77,57$.

(E)-tert Butyl 3-(3-quinolyl)prop-2-enoate (13). Colorless crystals, mp. 131-132 ${ }^{\circ} \mathrm{C}$; ${ }^{1} \mathrm{H}$ NMR $\left(\mathrm{CDCl}_{3}\right) \delta 1.54\left(\mathrm{~s}, 9 \mathrm{H}, \mathrm{C}\left(\mathrm{CH}_{3}\right)_{3}\right), 6.56(\mathrm{~d}, 1 \mathrm{H}, J=16.04 \mathrm{~Hz}), 7.51-7.55(\mathrm{~m}, 1 \mathrm{H}), 7.68-7.72(\mathrm{~m}$, $1 \mathrm{H}), 7.70(\mathrm{~d}, 1 \mathrm{H}, J=16.04 \mathrm{~Hz}), 7.79(\mathrm{~d}, 1 \mathrm{H}, J=8.2 \mathrm{~Hz}), 8.07(\mathrm{~d}, 1 \mathrm{H}, J=8.2 \mathrm{~Hz}), 8.16(\mathrm{~d}, 1 \mathrm{H}, J$ $=1.88 \mathrm{~Hz}), 9.04(\mathrm{~d}, 1 \mathrm{H}, J=2.04 \mathrm{~Hz}) ;{ }^{13} \mathrm{C} \mathrm{NMR} \delta 28.5,81.3,122.4,127.6,127.9,128.0,128.54$, 129.6, 130.7, 135.5, 140.3, 148.7, 149.5, 166.0; MS (m/e) $255\left(\mathrm{M}^{+}\right), 199,182,170,153,127$, 101, 77, 57. Anal. Calcd for $\mathrm{C}_{16} \mathrm{H}_{17} \mathrm{NO}_{2}$ : C, 75.27; H, 6.71; N, 5.49. Found: C, 75.28; H, 6.82; N, 5.45 .

(E)-tert Butyl 3-(4-isoquinolyl)prop-2-enoate (14). Colorless crystals, mp. 85-86 ${ }^{\circ}$; ${ }^{1} \mathrm{H} \mathrm{NMR}$ $\left(\mathrm{CDCl}_{3}\right) \delta 1.58\left(\mathrm{~s}, 9 \mathrm{H}, \mathrm{C}\left(\mathrm{CH}_{3}\right)_{3}\right), 6.53(\mathrm{~d}, 1 \mathrm{H}, J=15.96 \mathrm{~Hz}), 7.65(\mathrm{dd}, 1 \mathrm{H}, J=7.28,7.8 \mathrm{~Hz})$, $7.75-7.8(\mathrm{~m}, 1 \mathrm{H}), 8.0(\mathrm{~d}, 1 \mathrm{H}, J=8.16 \mathrm{~Hz}), 8.13(\mathrm{~d}, 1 \mathrm{H}, J=8.52 \mathrm{~Hz}), 8.26(\mathrm{~d}, 1 \mathrm{H}, J=15.96 \mathrm{~Hz})$, $8.73(\mathrm{~s}, 1 \mathrm{H}), 9.22(\mathrm{~s}, 1 \mathrm{H}) ;{ }^{13} \mathrm{C}$ NMR $\delta 28.5,81.3,122.9,124.5,126.2,127.8,128.3,128.5,131.4$, 133.9, 137.8, 141.7, 154.0, 165.9; MS (m/e) $255\left(\mathrm{M}^{+}\right), 199,182,154,127,100,77$, 57. Anal. Calcd for $\mathrm{C}_{16} \mathrm{H}_{17} \mathrm{NO}_{2}$ : C, 75.27; H, 6.71; N, 5.49. Found: C, 74.90; H, 6.45; N, 5.41.

(E)-tert-Butyl 3-(2-thienyl)prop-2-enoate (15). ${ }^{39}$ Pale yellow liquid, ${ }^{1} \mathrm{H}$ NMR $\left(\mathrm{CDCl}_{3}\right) \delta 1.52$ $\left(\mathrm{s}, 9 \mathrm{H}, \mathrm{C}\left(\mathrm{CH}_{3}\right)_{3}\right), 6.17(\mathrm{~d}, 1 \mathrm{H}, J=15.72 \mathrm{~Hz}), 7.01-7.04(\mathrm{~m}, 1 \mathrm{H}), 7.21(\mathrm{~d}, 1 \mathrm{H}, J=3.76 \mathrm{~Hz}), 7.33$ $(\mathrm{d}, 1 \mathrm{H}, J=4.8 \mathrm{~Hz}), 7.67(\mathrm{~d}, 1 \mathrm{H}, J=15.72 \mathrm{~Hz}) ;{ }^{13} \mathrm{C}$ NMR $\delta 28.5,80.8,119.4,128.2,128.3$, 130.7, 136.3, 140.1, 166.4; MS (m/e) $210\left(\mathrm{M}^{+}\right), 154,137,121,109,97,82,65,57\left(\mathrm{C}_{11} \mathrm{H}_{14} \mathrm{O}_{2} \mathrm{~S}\right.$ requires $\left.\mathrm{M}^{+}=210\right)$..

(E)-4-Acetylstilbene (17a). Colorless crystals, mp. 143-144 ${ }^{\circ} \mathrm{C}$ (ref. $\left.{ }^{40} \mathrm{mp} .141-142{ }^{\circ} \mathrm{C}\right) ;{ }^{1} \mathrm{H} \mathrm{NMR}$ $\left(\mathrm{CDCl}_{3}\right) \delta 2.58\left(\mathrm{~s}, 3 \mathrm{H}, \mathrm{CH}_{3} \mathrm{CO}\right), 7.10(\mathrm{~d}, 1 \mathrm{H}, J=16.4 \mathrm{~Hz}), 7.20(\mathrm{~d}, 1 \mathrm{H}, J=16.4 \mathrm{~Hz}), 7.27-7.31$ $(\mathrm{m}, 1 \mathrm{H}), 7.36(\mathrm{~m}, 2 \mathrm{H}), 7.51-7.53(\mathrm{~m}, 2 \mathrm{H}), 7.56(\mathrm{~d}, 1 \mathrm{H}, J=8.4 \mathrm{~Hz}), 7.93(\mathrm{~d}, 1 \mathrm{H}, J=8.4 \mathrm{~Hz}) ;{ }^{13} \mathrm{C}$ NMR $\delta 26.9,126.8,127.1,127.7,128.6,129.1,129.2,131.7,136.2,136.9,142.3,197.7$; MS $(m / e) 222\left(\mathrm{M}^{+}\right), 207,178,152,103,89,76,63,51\left(\mathrm{C}_{16} \mathrm{H}_{14} \mathrm{O}\right.$ requires $\left.\mathrm{M}^{+}=222\right)$..

(E)-2-Chloro-5-( $\beta$-styryl)pyridine (18a). Yellow crystals, mp. $83-84^{\circ} \mathrm{C}$ (ref. $\left.{ }^{41} \mathrm{mp} .84-85^{\circ} \mathrm{C}\right)$; ${ }^{1} \mathrm{H}$ NMR $\left(\mathrm{CDCl}_{3}\right) \delta 7.02(\mathrm{~d}, 1 \mathrm{H}, J=16.36 \mathrm{~Hz}), 7.13(\mathrm{~d}, 1 \mathrm{H}, J=16.36 \mathrm{~Hz}), 7.26-7.32(\mathrm{~m}, 2 \mathrm{H})$, $7.38(\mathrm{dd}, 2 \mathrm{H}, J=7.52,7.16 \mathrm{~Hz}), 7.51(\mathrm{~d}, 2 \mathrm{H}, J=7.16 \mathrm{~Hz}), 7.79(\mathrm{dd}, 1 \mathrm{H}, J=8.2,2.36 \mathrm{~Hz}), 8.46$ $(\mathrm{d}, 1 \mathrm{H}, J=2.36 \mathrm{~Hz}) ;{ }^{13} \mathrm{C}$ NMR $\delta 123.7,124.5,127.1,128.8,129.2,131.9,132.4,135.6,136.7$, 
148.5, 150.3; MS $(m / e) 215\left(\mathrm{M}^{+}\right), 178,151,127,107,89,76,63,51\left(\mathrm{C}_{13} \mathrm{H}_{10} \mathrm{ClN}\right.$ requires $\mathrm{M}^{+}=$ 215)..

2-Chloro-5-( $\alpha$-styryl)pyridine (18b). Colorless oil; ${ }^{1} \mathrm{H} \mathrm{NMR}\left(\mathrm{CDCl}_{3}\right) \delta 5.54(\mathrm{~d}, 2 \mathrm{H}, J=16.65$, $0.64 \mathrm{~Hz}), 7.27-7.39(\mathrm{~m}, 6 \mathrm{H}), 7.57$ (dd, $1 \mathrm{H}, J=8.28,2.52 \mathrm{~Hz}), 8.4$ (d, 1H, $J=2.52 \mathrm{~Hz}) . \mathrm{MS}(m / e)$ $215\left(\mathrm{M}^{+}\right), 200,180,165,151,127,103,89,76,63,51\left(\mathrm{C}_{13} \mathrm{H}_{10} \mathrm{ClN}\right.$ requires $\left.\mathrm{M}^{+}=215\right)$.

(E)-3-( $\beta$-Styryl)pyridine (19a). Yellow crystals, mp. $80-81^{\circ} \mathrm{C}$ (ref. $\left.{ }^{42} \mathrm{mp} .81-83^{\circ} \mathrm{C}\right)$; ${ }^{1} \mathrm{H}$ NMR $\left(\mathrm{CDCl}_{3}\right) \delta 7.04(\mathrm{~d}, 1 \mathrm{H}, J=16.4 \mathrm{~Hz}), 7.14(\mathrm{~d}, 1 \mathrm{H}, J=16.4 \mathrm{~Hz}), 7.23-7.29(\mathrm{~m}, 2 \mathrm{H}), 7.37(\mathrm{dd}, 2 \mathrm{H}$, $J=7.84,7.16 \mathrm{~Hz}), 7.50(\mathrm{~d}, 2 \mathrm{H}, J=7.2 \mathrm{~Hz}), 7.78-7.81(\mathrm{~m}, 1 \mathrm{H}), 8.47$ (dd, $1 \mathrm{H}, J=4.76,1.68 \mathrm{~Hz})$, $8.7(\mathrm{~d}, 1 \mathrm{H}, J=2.36 \mathrm{~Hz}) ;{ }^{13} \mathrm{C}$ NMR $\delta 123.8,125.1,126.9,128.5,129,131,132.9,133.2,136.9$, 148.8; MS (m/e) $181\left(\mathrm{M}^{+}\right), 152,127,102,90,76,51$.

(E)-3-( $\beta$-Styryl)quinoline (20a). Light yellow crystals, mp. $97-98^{\circ} \mathrm{C}$ (ref. ${ }^{43} \mathrm{mp} .98-99^{\circ} \mathrm{C}$ ); ${ }^{1} \mathrm{H}$ $\operatorname{NMR}\left(\mathrm{CDCl}_{3}\right) \delta 7.21(\mathrm{~d}, 1 \mathrm{H}, J=16.4 \mathrm{~Hz}), 7.28-7.30(\mathrm{~m}, 1 \mathrm{H}), 7.31(\mathrm{~d}, 1 \mathrm{H}, J=16.4 \mathrm{~Hz}), 7.38-$ $7.41(\mathrm{~m}, 2 \mathrm{H}), 7.51-7.58(\mathrm{~m}, 3 \mathrm{H}), 7.64-7.68(\mathrm{~m}, 1 \mathrm{H}), 7.79(\mathrm{~d}, 1 \mathrm{H}, J=7.88 \mathrm{~Hz}), 8.09(\mathrm{~d}, 1 \mathrm{H}, J=$ $8.52 \mathrm{~Hz}), 8.13(\mathrm{~d}, 1 \mathrm{H}, J=1.68 \mathrm{~Hz}), 9.11(\mathrm{~d}, 1 \mathrm{H}, J=2.04 \mathrm{~Hz}) ;{ }^{13} \mathrm{C}$ NMR $\delta 125.5,127.0,127.3$, 128.1, 128.4, 128.6, 129.1, 129.5, 129.6, 130.6, 131.2, 132.6, 137.1, 147.8, 149.8; MS (m/e) 231 $\left(\mathrm{M}^{+}\right), 216,202,127,115,101,76,63,51$.

3-( $\alpha$-Styryl)quinoline (20b). Pale yellow oil; ${ }^{1} \mathrm{H}$ NMR $\left(\mathrm{CDCl}_{3}\right) \delta 5.66(\mathrm{~d}, 2 \mathrm{H}, J=7.16 \mathrm{~Hz})$, $7.38(\mathrm{~m}, 5 \mathrm{H}), 7.54(\mathrm{dd}, 1 \mathrm{H}, J=7.84,7.16 \mathrm{~Hz}), 7.69-7.73(\mathrm{~m}, 1 \mathrm{H}), 7.77(\mathrm{~d}, 1 \mathrm{H}, J=7.84 \mathrm{~Hz})$, $8.04(\mathrm{~d}, 1 \mathrm{H}, J=1.68 \mathrm{~Hz}), 8.12(\mathrm{~d}, 1 \mathrm{H}, J=8.56 \mathrm{~Hz}), 8.95(\mathrm{~d}, 1 \mathrm{H}, J=2.04 \mathrm{~Hz}) ;{ }^{13} \mathrm{C}$ NMR (DEPT) $\delta 116.6\left(\mathrm{CH}_{2}\right), 127.2,128.3,128.5,128.6,128.9,129.5,129.9,135.1,150.9(\mathrm{CH}), 128.0,134.6$, 140.8, 147.4, 147.9 (C); MS (m/e) $231\left(\mathrm{M}^{+}\right), 216,202,126,115,101,88,76,51$. HRMS, Calcd for $\mathrm{C}_{17} \mathrm{H}_{13} \mathrm{~N}: 231.10$. Found: $232.1126\left(\mathrm{MH}^{+}\right)$.

(E)-4-( $\beta$-Styryl)isoquinoline (21a). Pale yellow powder, mp. $73-74^{\circ} \mathrm{C}$ (ref. ${ }^{44} \mathrm{mp} .75^{\circ} \mathrm{C}$ ); ${ }^{1} \mathrm{H}$ NMR $\left(\mathrm{CDCl}_{3}\right) \delta 7.20(\mathrm{~d}, 1 \mathrm{H}, J=16.04 \mathrm{~Hz}), 7.31-7.34(\mathrm{~m}, 1 \mathrm{H}), 7.39-7.43(\mathrm{~m}, 2 \mathrm{H}), 7.60-7.76(\mathrm{~m}$, $5 \mathrm{H}), 8.0(\mathrm{~d}, 1 \mathrm{H}, J=8.12 \mathrm{~Hz}), 8.16(\mathrm{~d}, 1 \mathrm{H}, J=8.4 \mathrm{~Hz}), 8.76(\mathrm{~s}, 1 \mathrm{H}), 9.18(\mathrm{~s}, 1 \mathrm{H}) ;{ }^{13} \mathrm{C} \mathrm{NMR} \delta$ $122.8,123.3,127.2$, 127.5, 128.4, 128.5, 128.6, 128.9, 129.1, 130.8, 133.5, 134.1, 137.4, 140.8, 152.2; MS (m/e) $231\left(\mathrm{M}^{+}\right), 202,175,153,128,115,101,88,76$.

4-( $\alpha$-Styryl)isoquinoline (21b). Colorless crystals, mp. $90-92^{\circ} \mathrm{C} ;{ }^{1} \mathrm{H}$ NMR $\left(\mathrm{CDCl}_{3}\right) \delta 5.45(\mathrm{~d}$, $1 \mathrm{H}, J=1.28 \mathrm{~Hz}), 6.0(\mathrm{~d}, 1 \mathrm{H}, J=1.16 \mathrm{~Hz}), 7.27-7.33(\mathrm{~m}, 5 \mathrm{H}), 7.52-7.57(\mathrm{~m}, 2 \mathrm{H}), 7.64(\mathrm{~d}, 1 \mathrm{H}, J$ $=7.52 \mathrm{~Hz}), 8.0(\mathrm{~d}, 1 \mathrm{H}, J=7.16 \mathrm{~Hz}), 8.51(\mathrm{~s}, 1 \mathrm{H}), 9.26(\mathrm{~s}, 1 \mathrm{H}) ;{ }^{13} \mathrm{C} \mathrm{NMR}(\mathrm{DEPT}) \delta 117.9\left(\mathrm{CH}_{2}\right)$, 125.7, 126.9, 127.4, 128.1, 128.4, 128.9, 130.6, 143.5, $152.9(\mathrm{CH}), 129.3,133.3,134.8,140.8$, 145.4 (C); MS (m/e) $231\left(\mathrm{M}^{+}\right), 202,154,115,101,88,77,51$. HRMS, Calcd for $\mathrm{C}_{17} \mathrm{H}_{13} \mathrm{~N}$ : 231.10. Found: $232.1126\left(\mathrm{MH}^{+}\right)$.

(E)-2-( $\beta$-Styryl)thiophene (22a). Colorless crystals, mp. $109-110^{\circ} \mathrm{C}\left(\right.$ ref. $\left.^{45} \mathrm{mp} .112-113^{\circ} \mathrm{C}\right) ;{ }^{1} \mathrm{H}$ $\operatorname{NMR}\left(\mathrm{CDCl}_{3}\right) \delta 6.92(\mathrm{~d}, 1 \mathrm{H}, J=16.04 \mathrm{~Hz}), 6.98-7.0(\mathrm{dd}, 1 \mathrm{H}, J=5.12,5.12 \mathrm{~Hz}), 7.05(\mathrm{~d}, 1 \mathrm{H}, J$ $=3.4 \mathrm{~Hz}), 7.17(\mathrm{~d}, 1 \mathrm{H}, J=5.12 \mathrm{~Hz}), 7.22(\mathrm{~d}, 1 \mathrm{H}, J=16.04 \mathrm{~Hz}), 7.22-7.25(\mathrm{~m}, 1 \mathrm{H}), 7.31-7.35$ $(\mathrm{dd}, 2 \mathrm{H}, J=7.84,7.2 \mathrm{~Hz}), 7.45(\mathrm{~d}, 1 \mathrm{H}, J=7.52 \mathrm{~Hz}) ;{ }^{13} \mathrm{C}$ NMR (DEPT) $\delta 122.1,124.7,126.4$, 126.6, 127.9, 128.7, 129, 137.3, 143.2; MS (m/e) $185\left(\mathrm{M}^{+}\right), 171,152,141,115,102,92,79,63$.

4-(Phenylethynyl)acetophenone (24). Colorless crystals, mp. $100-101^{\circ} \mathrm{C}$ (ref. ${ }^{46} \mathrm{mp} .98-99^{\circ} \mathrm{C}$ ); ${ }^{1} \mathrm{H}$ NMR $\left(\mathrm{CDCl}_{3}\right) \delta 2.60\left(\mathrm{~s}, 3 \mathrm{H}, \mathrm{CH}_{3} \mathrm{CO}\right), 7.36-7.38(\mathrm{~m}, 2 \mathrm{H}), 7.54-7.56(\mathrm{~m}, 3 \mathrm{H}), 7.60(\mathrm{~d}, 2 \mathrm{H}, J=$ 
$8.56 \mathrm{~Hz}), 7.93(\mathrm{~d}, 2 \mathrm{H}, J=8.56 \mathrm{~Hz}) ;{ }^{13} \mathrm{C} \mathrm{NMR} \delta 26.9,88.9,93.0,122.9,128.5,128.6,128.8$, 129.1, 132.0, 132.1, 136.5, 197.6; MS (m/e) $220\left(\mathrm{M}^{+}\right), 205,176,151,126,103,75,51$.

2-Chloro-5-(phenylethynyl)pyridine (25). Pale yellow crystals, mp. $68-69^{\circ} \mathrm{C}$; ${ }^{1} \mathrm{H}$ NMR $\left(\mathrm{CDCl}_{3}\right) \delta 7.30-7.33(\mathrm{~d}, 1 \mathrm{H}, J=8.28 \mathrm{~Hz}), 7.35-7.39(\mathrm{~m}, 3 \mathrm{H}), 7.53-7.56(\mathrm{~m}, 2 \mathrm{H}), 7.73-7.76(\mathrm{dd}$, $1 \mathrm{H}, J=8.28,2.4 \mathrm{~Hz}), 8.54(\mathrm{~d}, 1 \mathrm{H}, J=2.0 \mathrm{~Hz}) ;{ }^{13} \mathrm{C} \mathrm{NMR} \delta 85.0,94.1,119.7,122.5,124.2$, 128.8, 129.4, 132.0, 141.2, 150.7, 152.3; MS (m/e) $215\left(\mathrm{M}^{+}+2\right), 214\left(\mathrm{M}^{+}+1\right), 213\left(\mathrm{M}^{+}\right), 177$, 151, 126, 107, 98, 75, 62, 51. Anal. Calcd for $\mathrm{C}_{13} \mathrm{H}_{8} \mathrm{ClN}$ : C, 73.08; H, 3.77; N, 6.56. Found: C, $73.21 ; \mathrm{H}, 3.59 ; \mathrm{N}, 6.28$.

3-(Phenylethynyl)pyridine (26). Pale yellow crystals, mp. $48-49^{\circ} \mathrm{C}$ (ref. ${ }^{47} \mathrm{mp} .50-51^{\circ} \mathrm{C}$ ); ${ }^{1} \mathrm{H}$ NMR $\left(\mathrm{CDCl}_{3}\right) \delta 7.25-7.28(\mathrm{ddd}, 1 \mathrm{H}, J=8.80,7.88,0.88 \mathrm{~Hz}), 7.34-7.38(\mathrm{~m}, 3 \mathrm{H}), 7.52-7.56(\mathrm{~m}$, 2H), 7.78-7.81 (dt, $1 \mathrm{H}, J=7.88,1.88 \mathrm{~Hz}), 8.53$ (dd, $1 \mathrm{H}, J=4.92,1.6 \mathrm{~Hz}), 8.76$ (d, $1 \mathrm{H}, J=1.6$ $\mathrm{Hz}) ;{ }^{13} \mathrm{C}$ NMR $\delta 86.2,92.9,120.8,122.8,123.3,128.7,129.1,131.9,138.7,148.8,152.5$; MS (m/e) $179\left(\mathrm{M}^{+}\right), 151,126,102,90,76,63,50$.

3-(Phenylethynyl)quinoline (27). Pale yellow crystals, mp. $50-51^{\circ} \mathrm{C}\left(\right.$ ref. $\left.^{48} \mathrm{mp} .46-48^{\circ} \mathrm{C}\right)$; 7.36$7.40(\mathrm{~m}, 3 \mathrm{H}), 7.54-7.61(\mathrm{~m}, 3 \mathrm{H}), 7.69-7.74(\mathrm{~m}, 1 \mathrm{H}), 7.79(\mathrm{~d}, 1 \mathrm{H}, J=8.16 \mathrm{~Hz}), 8.10(\mathrm{~d}, 1 \mathrm{H}, J=$ $8.52 \mathrm{~Hz}), 8.30(\mathrm{~d}, 1 \mathrm{H}, J=2.04 \mathrm{~Hz}), 9.0(\mathrm{~d}, 1 \mathrm{H}, J=2.08 \mathrm{~Hz}) ;{ }^{13} \mathrm{C}$ NMR $\delta 86.9,92.9,117.8$, $122.9,127.5,127.6,127.9,128.8,129.1,129.7,130.4,132.1,138.6,147.1,152.4$; MS (m/e) 229 $\left(\mathrm{M}^{+}\right), 200,175,150,126,114,101,88,75,50$.

2-(Phenylethynyl)thiophene (28). Colorless crystals, mp. 49-50 ${ }^{\circ} \mathrm{C}$ (ref. ${ }^{49} \mathrm{mp} .49-51{ }^{\circ} \mathrm{C}$ ); ${ }^{1} \mathrm{H}$ $\operatorname{NMR}\left(\mathrm{CDCl}_{3}\right) \delta 7.03(\mathrm{dd}, 1 \mathrm{H}, J=5.12,5.12 \mathrm{~Hz}), 7.30-7.32(\mathrm{~m}, 2 \mathrm{H}), 7.36-7.40(\mathrm{~m}, 3 \mathrm{H}), 7.54-$ $7.57(\mathrm{~m}, 2 \mathrm{H}) ;{ }^{13} \mathrm{C}$ NMR $\delta 82.9,93.4,123.2,123.6,127.4,127.6,128.6,128.7,131.7,132.2$; MS $(m / e) 184\left(\mathrm{M}^{+}\right), 152,139,126,113,92,79,63,45$.

2-Phenylbenzo[b]furan (32). White powder, mp. $117-118^{\circ} \mathrm{C}$ (ref. ${ }^{50} \mathrm{mp} .118-120^{\circ} \mathrm{C}$ ); ${ }^{1} \mathrm{H}$ NMR $\left(\mathrm{CDCl}_{3}\right) \delta 7.03(\mathrm{~s}, 1 \mathrm{H}), 7.22-7.38(\mathrm{~m}, 3 \mathrm{H}), 7.44-7.48(\mathrm{~m}, 2 \mathrm{H}), 7.53-7.60(\mathrm{~m}, 2 \mathrm{H}), 7.88(\mathrm{dd}, 2 \mathrm{H}, J$ $=7.2,1.36 \mathrm{~Hz}) ;{ }^{13} \mathrm{C}$ NMR $\delta 101.6,111.5,121.2,123.3,124.6,125.3,128.9,129.1,130.8,132.8$, 155.2, 156.3; MS (m/e) $194\left(\mathrm{M}^{+}\right), 165,139,115,97,82,69$.

5-Chloro-2-phenylbenzo[b]furan (33). Yellowish crystals, mp. $154-156^{\circ} \mathrm{C}$ (ref. $^{50} \mathrm{mp} .155-$ $\left.157^{\circ} \mathrm{C}\right) ;{ }^{1} \mathrm{H} \mathrm{NMR}\left(\mathrm{CDCl}_{3}\right) \delta 6.96(\mathrm{~s}, 1 \mathrm{H}), 7.23(\mathrm{dd}, 1 \mathrm{H}, J=8.68,2.12 \mathrm{~Hz}), 7.36-7.48(\mathrm{~m}, 4 \mathrm{H})$, $7.55(\mathrm{~d}, 1 \mathrm{H}, J=2 \mathrm{~Hz}), 7.85$ (d, 2H, $J=8.64 \mathrm{~Hz}) ;{ }^{13} \mathrm{C} \mathrm{NMR} \delta 101.1,112.5,120.7,124.7,125.4$, 128.8, 129.2, 129.3, 130.3, 130.9, 153.6, 157.7. MS (m/e) $228\left(\mathrm{M}^{+}\right), 199,165,139,114,82,69$.

\section{Acknowledgements}

This work was supported by the DFG (Ki 397 / 6-1). K. M. Dawood is deeply indebted to the Alexander-von-Humboldt Foundation for granting him a postdoctoral fellowship (AGY1113724STP). We thank U. Kunz (Technical University of Clausthal) for providing us with polymer glass composite material. 


\section{References}

1. Reviews on immobilized catalysts: (a) Kirschning, A., Ed., Immobilized Catalysts In Top. Curr. Chem. 2004, Vol. 242. (b) Solodenko, W.; Frenzel, T.; Kirschning, A. In Polymeric Materials in Organic Synthesis and Catalysis, Buchmeiser, M. R.; Ed., Wiley-VCH; Weinheim, 2003, pp 201-240. (c) Clapham, B.; Reger, T. S.; Janda, K. D. Tetrahedron 2001, 57, 4637. (d) Gladysz, J. A. Chem. Rev. 2002, 102, 3215. (e) McNamara, C. A.; Dixon, M. J.; Bradley, M. Chem. Rev. 2002, 102, 3275.

2. Blaser, H.-U. Chem. Commun. 2003, 293 (b) Blaser, H.-U.; Siegrist, U.; Steiner, H. M. in Fine Chemicals through Heterogeneous Catalysis, Sheldon, R.A.; van Bekkum H., Eds., Wiley-VCH; Weinheim, 2001, 389. (c) Schöning, K.U.; End, N. In Immobilized Catalysts, Kirschning, A., Ed., Top. Curr. Chem. 2004, 242, pp. 241-273 and 273-319; (d) Blaser, H.U.; Indolese, A.; Naud, F.; Nettekoven, U.; Schnyder, A. Adv. Synth. Catal. 2004, 346, 1583.

3. Reviews on microwave assisted synthesis: (a) Cablewski, T.; Faux, A. F.; Strauss, C. R. J. Org. Chem. 1994, 59, 3408. (b) Microwaves in Organic Synthesis, Loupy, A., Ed., WileyVCH; Weinheim, 2002. (c) Kappe, C. O. Curr. Opin. Chem.Biol. 2002, 6, 314. (d) Desai, B.; Kappe, C. O. In Immobilized Catalysts, Kirschning, A., Ed., Top. Curr. Chem. 2004, 242, pp 177-208. (e) Kappe, C. O. Angew. Chem. Int. Ed. 2004, 43, 6250. (f) Hoz, A.; Ortiz, A. D.; Moreno, A. Chem. Soc. Rev. 2005, 34, 164.

4. (a) Solodenko, W.; Schön, U.; Messinger, J.; Glinschert, A..; Kirschning, A. Synlett 2004, 1699. (b) Erdelyi, M.; Gogoll, A. J. Org. Chem. 2003, 68, 6431. (c) Organ, M. G.; Mayer, S.; Lepifre, F.; N'Zemba, B.; Khatri, J. Mol. Div. 2003, 2-4, 211.

5. (a) Solodenko, W.; Brochwitz, C.; Wartchow, R.; Hashem, Md. A.; Dawood, K. M.; Vaultier, M.; Kirschning, A. Mol. Div. 2005, 9, 333. (b) Dawood, K.M.; Kirschning, A. Tetrahedron 2005, 61, 12121.

6. For reviews on the palladium-catalyzed Mizoroki-Heck cross-coupling reaction, see: (a) Crisp, G. T. Chem. Soc. Rev. 1998, 27, 427. (b) Diederich, F.; Stang, J. P. Metal-Catalyzed Cross-coupling Reactions, Wiley-VCH; Weinheim, 1998. (c) Bourissou, D.; Guerret, O.; Gabbai, F. P.; Betrand, G. Chem. Rev. 2000, 100, 39. (d) Dupont, J.; M. Pfeffer, M.; Spencer, J. Eur. J. Inorg. Chem. 2001, 1971. (e) Miyaura, N. Cross-Coupling Reaction, Springer; Berlin, 2002. (f) Hegedus L. S. In Organometallics in Synthesis, Schlosser, M., Ed., J. Wiley \& Sons: Chichester, 2002, p 1123. (g) van der Boom, M. E.; Milstein, D. Chem. Rev. 2003, 103, 1759. (h) Dounay, A. B.; Overman, L. E. Chem. Rev. 2003, 103, 2945. (i) Phan, N. T. S.; Van Der Sluys, M.; Jones, C. W. Adv. Synth. Catal. 2006, 348, 609679.

7. (a) Sonogashira, K. In Metal-Catalyzed Cross-Coupling Reactions, Diederich, F.; Stang, P. J., Eds., Wiley-VCH: New York, 1998, Chap. 5. (b) Brandsma, L.; Vasilevsky, S. F.; Verkruijsse, H. D. Application of Transition Metal Catalysts in Organic Synthesis, SpringerVerlag: Berlin, 1998, Chap. 10. (c) Rossi, R.; Carpita, A.; Bellina, F. Org. Prep. Proced. Int. 
1995, 27, 127. (d) Sonogashira, K. In Comprehensive Organic Synthesis, Trost, B. M., Ed., Pergamon: New York, 1991, Vol. 3, Chap. 2.4.

8. (a) Sonogashira, K.; Tohda, Y.; Hagihara, N. Tetrahedron Lett. 1975, 4467. (b) Nicolaou, K. C.; Ladduwahetty, T.; Taffer, I. M.; Zipkin, R. E. Synthesis 1986, 344. (c) Shiga, F.; Yasuhara, A.; Uchigawa, D.; Kondo, Y.; Sakamotot, T.; Yamanaka, H. Synthesis 1992, 746. (d) Graham, A. E.; McKerrecher, D.; Davies, D. H.; Taylor, R. J. K. Tetrahedron Lett. 1996, 37, 7445. (e) Miller, M. W.; Johnson, C. R. J. Org. Chem. 1997, 62, 1582.

9. Farina, V. Adv. Synth. Catal. 2004, 346, 1553. (b) Dupont, J.; Consorti, C. S.; Spencer, J. Chem. Rev. 2005, 105, 2527.

10. Nowotny, M.; Hanefeld, U.; van Koningsveld, H.; Maschmeyer, T. Chem. Commun. 2000, 1877.

11. C.-A. Lin, C.-A.; Luo, F.-T. Tetrahedron Lett. 2003, 44, 7565.

12. (a) Bergbreiter, D. E.; Osburn, P. L.; Liu, Y.-S. J. Am. Chem. Soc. 1999, 121, 9531. (b) Bergbreiter, D. E.; Osburn, P. L.; Frels, J. D. J. Am. Chem. Soc. 2001, 123, 11105. (c) Bergbreiter, D. E.; Osburn, P. L.; Frels, J. D. Adv. Synth. Catal. 2005, 347, 172.

13. Mehnert, C. P.; Ying, J. Y. J. Chem. Soc., Chem. Commun. 1997, 2215. (b) Mehnert, C. P.; Weaver, D. W.; Ying, J. Y. J. Am. Chem. Soc. 1998, 120, 12289. (c) Tsai, F.-Y.; Wu, C.-L.; Mou, C.-Y.; Chao, M.-C.; Lin, H.-P.; Liu, S.-T. Tetrahedron Lett. 2004, 45, 7503.

14. Gonthier, E.; Breinbauer, R. Synlett 2003, 1049.

15. Tyrell, E.; Al-Saadri, A.; Millet, J. Synlett 2005, 487.

16. (a) Leadbeater, N. E.; Tominack, B. J. Tetrahedron Lett. 2003, 44, 8653. (b) Li, J.-H.; Zhang, X.-D.; Xie, Y.-X. Synthesis 2005, 804. (c) Liang, B.; Dai, M.; Chen, J.; Yang, Z. J. Org. Chem. 2005, 70, 391.

17. Bumagin, N. A.; More, P. G.; Beletskaya, I. P. J. Organomet. Chem. 1989, 371, 397.

18. (a) Bradly, D.; Williams, G.; Lombard, H.; Holzapfel, C. W. Synth. Commun. 2001, 31, 2077. (b) Zhao, H.; Cai, M.-Z.; Hu, R.-H.; Song, C.-S. Synth. Commun. 2001, 31, 3665.

19. Mukhopadhyay, S.; Rothenberg, G.; Joshi, A.; Baidossi, M.; Sasson, Y. Adv. Synth. Catal. 2002, 344, 348.

20. Mukhopadhyay, S.; Rothenberg, G.; Joshi, A.; Baidossi, M.; Sasson, Y. Adv. Synth. Catal. 2002, 344, 348.

21. Nájera, C.; Gil-Molto, J.; Karlström, S.; Falvello, L. R. Org. Lett. 2003, 5, 1451.

22. Hou, J.-J.; Yang, L.-R.; Cui, X.-L.; Wu, Y.-J. Chinese J. Chem. 2003, 21, 717.

23. Botella, L.; Nájera, C. Tetrahedron Lett. 2004, 45, 1833.

24. Reviews on the Mizoroki-Heck reaction in aqueous solvents: (a) Heck, R. F. In Comprehensive Organic Synthesis; Trost, B. M.; Fleming, I., Eds., Pergamon Press: Oxford, 1991; Vol. 4. (b) De Meijere, A.; Meyer, F. Angew. Chem., Int. Ed. 1994, 33, 2379. (c) Malleron, J.-L.; Fiaud, J.-C.; Legros, J.-Y. Handbook of Palladium-Catalyzed Organic Reactions, Academic Press: London, 1997. (d) Anastas, P. T.; Warner, J., Eds., Green Chemistry: Theory and Practice, Oxford University Press: New York, 1998. (e) Herrmann, W. A.; Reisinger, C.-P. In Aqueous-Phase Organometallic Catalysis, Concepts and 
Applications, Cornils, B.; Herrmann, W. A., Eds., Wiley-VCH: Weinheim, 1998, pp 382392; (f) Beleskaya, I. P.; Cheprakov, A. V. Chem. Rev. 2000, 100, 3009. (g) Withcombe, N.; Hii-Mimi, K. K.; Gibson, S. Tetrahedron 2001, 57, 7449. (h) Larhed, M.; Hällberg, A. In Handbook of Organopalladium Chemistry for Organic Synthesis, Negishi, E.-I.; de Meijere, A., Eds., Wiley: New York, 2002, pp 1133-1178; (i) Littke, A.; Fu, G.. Angew. Chem., Int. Ed. 2002, 41, 4176.

25. (a) Botella, L.; Nájera, C. Tetrahedron 2004, 60, 5563. (b) Botella, L.; Nájera, C. Tetrahedron Lett., 2004, 45, 1833. (c) Botella, L.; Nájera, C. J. Org. Chem. 2005, 70, 4360.

26. de Vries, A. H. M.; Mulders, J. M. C. A.; Mommers, J. H. M.; Henderickx, H. J. W.; de Vries, J. G.. Org. Lett. 2003, 5, 3285. (b) Yu, K.; Sommer, W.; Richardson, J. M.; Weck, M.; Jones, C. W. Adv. Synth. Catal. 2005, 347, 161.

27. Reetz, M. T.; Westermann, E. Angew. Chem. Int. Ed. 2000, 39, 165. (b) Zapf, A.; Beller, M. Chem. Eur. J. 2001, 7, 2908.

28. Li, J.; Mau, A. W.-H.; Strauss, C. R. Chem. Commun. 1997, 1275. (b) Djakovitch, L.; Koehler, K. J. Mol. Catal. A: Chemical 1999, 142, 275. (c) Gruendemann, S.; Albrecht, M.; Loch, J. A.; Faller, J. W.; Crabtree, R. H. Organometallics 2001, 20, 5485. (d) Loch, J. A.; Albrecht, M.; Peris, E.; Mata, J.; Faller, J. W.; Crabtree, R. H. Organometallics 2002, 21, 700 .

29. Boehm, V. P. W.; Herrmann, W. A. Eur. J. Org. Chem. 2000, 22, 3679. (b) Hundertmark, T.; Littke, A. F.; Buchwald, S. L.; Fu, G. C. Org. Lett. 2000, 2, 1729. (c) Eckhardt, M.; Fu, G. C. J. Am. Chem. Soc. 2003, 125, 13642.

30. Siemsen, P.; Livingston, R. C.; Diederich, F. Angew. Chem., Int. Ed. 2000, 39, 2632. (b) Rossi, R.; Carpita, A.; Bigelli, C. Tetrahedron Lett. 1985, 26, 523. (c) Liu, Q.; Burton, D. J. Tetrahedron Lett. 1997, 38, 4371. (d) Liao, Y.; Fathi, R.; Reitman, M.; Zhang, Y.; Yang, Z. Tetrahedron Lett. 2001, 42, 1815. (e) Brase, S.; Gil, C.; Knepper, K. Bioorg. Med. Chem. 2002, 10, 2415. (f) Elangovan, A.; Wang, Y.-H.; Ho, T.-I. Org. Lett. 2003, 5, 1841.

31. Tzschucke, C. C.; Markert, C.; Glatz, H.; Bannwarth, W. Angew. Chem. Int. Ed. 2002, 41, 4500 .

32. (a) Walker, J. A.; Rossen, K.; Reamer, R. A.; Volante, R. P.; Reider, P. J. Tetrahedron Lett. 1999, 40, 4917. (b) Ganzalez, A. G.; Barrera, J. B.; Yanes, A. C.; Diaz, J. G.; Rodriguez, E. M. Phytochemistry 1989, 28, 2520. (c) Carvalho, C. F.; Sargent, M. V. J. Chem. Soc., Perkin Trans. 1 1984, 1605.

33. Vinh, T. K.; Ahmadi, M.; Delgado, P. O. L.; Prerez, S. F.; Walters, H. M.; Smith, H. J.; Nicholls, P. J.; Simons, C. Bioorg. Med. Chem. Lett. 1999, 9, 2105. (b) Tomaszewski, Z.; Johnson, M. P.; Haung, X.; Nichols, D. E. J. Med. Chem. 1992, 35, 2061. (c) Ellingboe, J. W.; Alessi, T. R.; Dolak, T. M.; Nguyen, T. T.; Tomer, J.D.; Guzzo, F.; Bagli, J.F.; McCaleb, M.L. J. Med. Chem. 1992, 35, 1176.

34. Larock, R. C. Palladium-Catalyzed Annulation of Alkynes, Top. Organomet. Chem., 2005, 14, pp 147-182. 
35. Copper-free Sonogashira cross coupling reactions of aryl iodides involving phosphine ligands was also performed with homogeneous palladium(II)-catalysts: (a) Kundu, N. G.; Pal, M.; Mahanty, J. S.; Dasgupta, S. K. J. Chem. Soc., Chem. Commun. 1992, 41. (b) Kundu, N. G.; Pal, M.; Mahanty, J. S.; De, M. J. Chem. Soc., Perkin Trans. 1 1997, 2815. (c) Bates, C. G.; Saejueng, P.; Murphy, J. M.; Venkataraman, D. Org. Lett. 2002, 4, 4727. (d) Hu, Y.; Nawoschik, K.J.; Liao, Y.; Ma, J.; Fathi, R.; Yang, Z. J. Org. Chem. 2004, 69, 2235.

36. (a) Torii, S.; Xu, L. H.; Okumoto. H. Synlett, 1992, 515. (b) Aquila, B. M. Tetrahedron Lett. 1997, 38, 2795. (c) Fancelli, D.; Fagnola, M. C.; Severino, D.; Bedeschi, A. Tetrahedron Lett. 1997, 38, 2311. (d) Botta, M.; Corelli, F.; Gasparrini, F.; Messina, F.; Mugnaini, C. J. Org. Chem. 2000, 65, 4736. (e) Dai, W.-M.; Lai, K. W. Tetrahedron Lett. 2002, 43, 9377. (f) Pal, M.; Subramanian, V.; Yeleswarapu, K. R. Tetrahedron Lett. 2003, 44, 8221. (g) Uozumi, Y.; Kobayashi, Y. Heterocycles 2003, 59, 71.

37. Li, G. Y.; Zheng, G.; Noonan, A. F. J. Org. Chem. 2001, 66, 8677. (b) Herrmann, W. A.; Brossmer, C.; Reisinger, C.-P.; Riermeier, T. H.; Ofele, K.; Beller, M. Chem. Eur. J. 1997, 3, 1357.

38. Bull, S. D.; Davies, S. G.; Fox, D. J.; Gianotti, M.; Kelly, P. M.; Pierres, C.; Savory, E. D.; Smith, A. D. J. Chem. Soc. Perkin Trans. 1 2002, 1858.

39. Lautens, M.; Mancuso, J.; Grover, H. Synthesis 2004, 2006.

40. (a) Denmark, S. E.; Wang, Z. Org. Lett. 2001, 3, 1073. (b) Bezou, P.; Hilberer, A.; Hadziioannou, G. Synthesis 1996, 449.

41. Arterburn, J. B.; Corona, C.; Rao, K. V.; Carlson, K. E.; Katzenellenbogen, J. A. J. Org. Chem. 2003, 68, 7063.

42. Giam, C. S. J. Org. Chem. 1981, 46, 4885.

43. Ishikura, M.; Oda, I.; Terashima, M. Heterocycles 1985, 23, 2375.

44. Loader, C. E.; Timmons, C. J. J. Chem. Soc., C, 1968, 330.

45. Sees, E. J.; Wilson, C. V. J. Org. Chem. 1961, 26, 5243.

46. Thorand, S.; Krause, N. J. Org. Chem. 1998, 63, 8551.

47. Mori, Y.; Seki, M. J. Org. Chem. 2003, 68, 1571.

48. Elangovan, A.; Yang, S.-W.; Lin, J.-H.; Kao, K.-M.; Ho, T.-I. Org. Biomol. Chem. 2004, 2, 1597.

49. Katritzky, A. R.; Abdel-Fattah, A. A. A.; Wang, M. J. Org. Chem. 2002, 67, 7526.

50. (a) Bates, C. G.; Saejueng, P.; Murphy, J. M.; Venkataraman, D. Org. Lett. 2002, 4, 4727.

(b) Deschamps-Vallet, C.; Ilotse, J.; Meyer-Dayan, M.; Motho, D. Tetrahedron Lett. 1979, 1109 